\title{
Domestic Systemically Important Banks: A Quantitative Analysis for the Chinese Banking System
}

\author{
Yibing Chen, ${ }^{1,2}$ Yong Shi, ${ }^{1,3}$ Xianhua Wei, ${ }^{2}$ and Lingling Zhang ${ }^{2}$ \\ ${ }^{1}$ Research Centre on Fictitious Economy and Data Science, Chinese Academy of Sciences, Beijing 100190, China \\ ${ }^{2}$ School of Management, University of Chinese Academy of Sciences, Beijing 100190, China \\ ${ }^{3}$ College of Information Science and Technology, University of Nebraska at Omaha, Omaha, NE 68182, USA
}

Correspondence should be addressed to Yong Shi; yshi@unomaha.edu

Received 14 December 2013; Accepted 9 February 2014; Published 26 March 2014

Academic Editor: Xiaodong Lin

Copyright (C) 2014 Yibing Chen et al. This is an open access article distributed under the Creative Commons Attribution License, which permits unrestricted use, distribution, and reproduction in any medium, provided the original work is properly cited.

\begin{abstract}
This paper serves as a response to the official assessment approach proposed by Basel Committee to identify domestic systemically important banks (D-SIBs) in China. Our analysis presents not only current levels of domestic systemic importance of individual banks but also the changes. We also consider the systemic risk of the whole banking system, by investigating how D-SIBs and non-D-SIBs are correlated before and after the recent financial crises using Copula. We find that the systemic importance of major banks is decreasing, while some banks becoming more systemically important should require tight regulations. D-SIBs as a whole subsystem display stronger correlation with non-D-SIBs than the individual D-SIBs, which alerts the regulatory to pay attention to "too-many-to-fail" problems. Contagion effects between D-SIBs and non-D-SIBs exist during the subprime crisis, but did not exist during the European debt crisis. This yields good signal of a more balanced banking system in China.
\end{abstract}

\section{Introduction}

Recent financial crises and financial contagion worldwide have brought the issue of Systemically Important Financial Institutions (SIFIs) into intense discussions [1]. Although there is no clear consensus on how systemic risk of an institution is measured, policy makers and regulators reach an agreement that identifying financial institutions whose viability is crucial for the smooth functioning of the overall financial system is essential (It is a positive definition for systemic relevance: financial institutions whose viability is crucial for the smooth functioning of the overall financial system. See [2]).

No SIFI definitions are commonly accepted; however, policy makers generally consider institutions as systemically important that cannot exist in the market without causing major disruption to the financial system [2]. The common characteristics of SIFI are being big in size, being too connected with other institutions, lack of substitutability, and also being complex in their business. Regulators are working on a new regulatory framework to address systemic risk, under which the designated systemically important institutions are candidates for tighter supervision and additional loss absorbency requirements to ensure financial stability.

In November 2011, the Basel Committee on Banking Supervision (BCBS) finalized its assessment methodology to identify Global Systemically Important Banks (G-SIBs) and mandate them to hold additional Common Tier 1 capital (on the top of minimum capital charges of Basel III) $[3,4]$. At the same time, Financial Stability Board identified an initial group of 29 banks as Global Systemically Important Banks, using the methodology developed by BCBS [5]. The list is updated annually based on new data and published by the FSB each November. In 2011 and 2012, only Bank of China in Chinese banking system is listed in the group $[5,6]$. This year's new list adds Industrial and Commercial Bank of China [7]. To date, there are two banks that are based in China among the 29 Global Systematically Important Banks, reflecting the indispensable role that China plays in global financial system.

Much progress has been achieved in identification and supervision of G-SIBs; however, there is much to be done 
dealing with domestic systemically important banks (DSIBs), which is also indispensable. As with the definition of G-SIBs, D-SIBs would have economically significant spillover effect upon their failures and would destabilize the financial system and have a negative impact on the real economy, especially within the nation it is located in [8]. As central bank increasingly define financial stability as a key mission, it is urgent for supervisors to attach additional importance to domestic systemically important banks. D-SIBs, much alike G-SIBs in nature, but only differing in range of activities, also require tighter supervision and additional loss absorbency requirements, as with the case of G-SIBs.

In 2011, the G20 Leaders asked the Basel Committee and the Financial Stability Board to work on modalities to extend expeditiously the G-SIB framework to D-SIBs. The BSBC then released a framework and provided guidance for dealing with domestic systemically important banks [9]. Scholars and regulators in many nations and regions including Australia [3], USA [10-13], Thailand [14], Brazil [15], and Hong Kong [16] explored several methods to access systemic importance or risk of individual banks, which help to identify their own D-SIBs.

China Banking Regulatory Commission (CBRC) also followed the BCBS assessment framework and proposed that size, interconnectedness, nonsubstitutability, and complexity should be considered when evaluating domestic systemic importance of banks in guidance on the implementation of the new Regulatory Standards for Chinese banking system (guidance on the implementation of the new Regulatory Standards for Chinese banking system, by CBRC. See http://www.cbrc.gov.cn/chinese/home/docView/

20110503615014F8D9DBF4F4FFE45843249ABE00.html).

However, to date, neither the number of D-SIBs in Chinese Banking system, nor the official assessment approach has been announced. Hence, domestic systemic risk in Chinese banking system as well as its relative distributions among banks remains unexamined. As Thomson [8] argued in his report, supervisory transparency is superior to constructive ambiguity for banking regulatory purpose. Therefore, both the list of D-SIBs and the methodology of assessment including indicators used should be made public. Therefore, a practical as well as transparent method is needed.

This paper serves as a response to assessment methodology of BCBS to help identify domestic systemically important banks in China. We intend to highlight relative proportion among the banks and also the change of the results as well. Besides D-SIBs identification, we also consider the systemic risk of the whole banking system, by investigating how DSIBs and non-D-SIBs are correlated before and after the recent financial crises.

The rest of this paper proceeds as follows. Section 2 reviews some relevant works on systemic important banks. Section 3 describes our methodology and data used in the study. Besides indicator-based measurement approach and its practical modification, we also introduce Copula, a nonlinear model to investigate how the banking system is correlated before and after the recent financial crises. Section 4 presents our quantitative results of the analysis. Section 5 is devoted to concluding remarks.

\section{Literature Review}

Issue of how to measure systemic importance of banks has drawn much attention in recent literatures, as a direct response to the regulatory requirement [12, 15, 18-22]. Most of the widely used approaches fall into the following two categories: market-based techniques and indicator-based approach [2].

Market-based techniques usually rely on information extracted from market prices and sophisticated financial models. Weistroffer et al. [2] distinguishes market-based techniques into two strands: in an additive manner and in a nonadditive manner. However, he leaves behind a large portion of studies that used network analysis. Therefore, according to the model structure, we classify market-based approaches into two buckets: network analysis and portfolio models.

Network analysis constructs a matrix of mutual exposures to describe the interconnectedness within the banking system [1]. With a hypothetical credit event to a specific bank, the researchers on this ground then simulate spillover from the credit event and assess the possible fallout for the rest of the system. The logic of the method is as follows: when a bank fails, it will trigger other banks' defaults resulting from their exposures (both direct and indirect) to the failing bank. Majority of the applied network literatures [15, 23] has focused on the interbank credit market due to data availability. Recently, Li et al. [24] developed a transfer entropy-based method to derive information from stock market, and determine the interbank exposure matrix when the exposure matrix data is not available.

Portfolio models were derived from measurement of risk in portfolio of security and extend to the measurement of systemic risk for a portfolio of banks [1]. The portfolio models follow two routines to measure a bank's systemic importance from different angles. "Bottom-up" approaches start with distress of a particular bank and then assess the associated system-wide distress. Conditional Value at Risk (CoVaR) is the important concept in this routine, which is defined as the value at risk of the banking system conditional on institutions in distress [10]. While "top-down" methods focused on examining the fragility of the overall banking system and required a methodology for allocating the overall risk into individual banks. Shapley Value [25] and Marginal Expected Shortfalls $[12,18,19]$ are the common measures derived from "top-down" routine.

Although market-based approaches play an important role in risk supervision, shortcomings such as lack of available data and market-based indicators' instability make them less suitable as supervisory benchmarks. In contrast with marketbased approach, policy makers tend to prefer a more handon approach using the available bank-level data (but not including market assessment). Market-based measures are only used as a cross-check if possible [2]. Besides, Drehmann and Tarashev [20] proved that some simple indicators (bank size, total interbank lending and borrowing) help approximate market-based measures of systemic importance. This research built the linkage between market-based approaches 
and indicator-based approaches and laid an empirical foundation for regulatory authorities' adoption of indicator-based for practical purpose. Similar work can also be found in [26].

Under indicator-based approach framework, choice of indicators and their respective weights is determined. Systemic importance of banks is then scored and ranked accordingly. The Basel Committee on Banking Supervision (BCBS) has developed an indicator-based approach for assessing systemic importance of Global Systemic Important Banks (GSIBs) [4]. Indicators of five categories are used to fully reflect a bank's systemic importance from different dimensions. The five categories are size, interconnectedness, nonsubstitutability, complexity, and cross-jurisdictional activity, with equal weight of $20 \%$. The assessment methodology provides guidance for the countries that attempt to assess domestic systemically important banks of their own. Braemer and Gischer [3] followed the official technique and made practical modification to determine the domestic systemic risk of each bank in Australia.

To be consistent with transparent requirement, the paper is much in line with the BCBS methodology under indicatorbased measurement approach while doing modifications to suit real situations in China. While the list of D-SIBs might be obvious, we intend to highlight relative proportion among the banks as well as the change of the results. Besides using indicator-based measurement approach to identify D-SIBs, we also consider the systemic risk of the whole banking system, by investigating how D-SIBs and non-D-SIBs are correlated before and after the recent financial crises using Copula. This part of analysis also provides cross-check of the D-SIBs identification based on market-based data.

\section{Methodology and Data}

3.1. Indicator-Based Measurement Approach. Systemic consequence of G-SIBs' failures can be dramatic but difficult to predict; therefore, Basel Committee requires G-SIBs to hold additional common Tier 1 capital on the top of Basel III standard in case of insolvency. If G-SIBs fail, they can be bailed out by the government.

To precisely identify which banks are G-SIBs, the BCBS indicator-based assessment methodology measures a bank's systemic importance from five dimensions: crossjurisdictional activity, size, interconnectedness, nonsubstitutability, and complexity [4]. All the categories have the equal weights of $20 \%$, and total score of each bank is summed from the five categories. The multiple indicators within a category are also equally weighted. Each value of an indicator is the individual bank amount divided by the aggregate amount across all the banks in the sample. Based on the score of systemic importance, the BCBS methodology classifies the banks into four different buckets with additional loss absorbency requirements varied from $1 \%$ to $2.5 \%$ accordingly. This methodology mainly aims to capture the impact that a failure of a bank may have on the global financial system and economy.

Our methodology for D-SIBs identification in Chinese banking system is much in line with the official BCBS indicator-based approach. In general, the difference lies in the choice of financial indicators due to data availability under the five categories depicting systemic importance, and also the weights of individual indicators within a certain category. Besides, a major adjustment is that the official category "crossjurisdictional activity" is changed to "public confidence" which was called "domestic sentiment" in Braemer and Gischer's work [3].

The categories that compose our measurement system of Chinese D-SIBs and the respective indicators within each category are presented and explained in Section 3.1.1. We describe our method based on entropy to determine the weights of indicators within each category and how to calculate the final score in Section 3.1.2.

\subsubsection{Indicators}

Size. The size of a bank is regarded as a key measure of systemic risk, as illustrated in the too-big-to-fail problem [22, 27]. In official BCBS approach, the size category is consisted of one single indicator "total exposure" of a bank, as defined in Basel III rule text [4].

However, the indicator "total exposures" requires both on-balance items and off-balance items, which are not available to the public. We instead adopt the common and observable proxy "total asset" on the balance sheet to reflect the relative size of a bank in the sample.

Interconnectedness. Systemic risk can rise through interlinkages between the nodes in banking network system both directly and indirectly [1]. If one bank defaults, it might not able to repay its interbank liabilities; therefore, the probability of other banks' distress increase or may lead to domino effects of default contagion within the interconnected system $[4,28]$.

Interconnectedness of a bank is measured by the volume of its intrafinancial system assets and intrafinancial system liabilities under the official BCBS approach, also with the wholesale funding ratio. However, in agreement with the work that identifies D-SIBs in Australia [3], we are skeptical that retail funding enhances financial stability. Therefore, we only include "intrafinancial system assets" and "intrafinancial system liabilities" in the category (We adjust the accounts under GAAP to ensure consistency; more details are provided in Table 15).

Intrafinancial system assets are the sum of the following.

(i) Due from banks and other financial institutions, which include deposits in banks and other financial institutions, and lendings to banks and other financial institutions.

(ii) Reverse repo agreement.

Intrafinancial system liabilities are the sum of the following.

(i) Due to banks and other financial institutions, which include deposits from banks and other financial institutions, and borrowings from banks and other financial institutions.

(ii) Repo agreement. 
Nonsubstitutability. A bank is systemic important within the system if it is difficult for other banks to provide the similar services in case of a default [2]. The Basel Committee regards an institution that plays a dominant role in a specific business segment or as a provider of market infrastructure as systemic important. The three indicators under this category designed by BCBS are "assets under custody," "payment cleared and settled through payment systems," and "value of underwritten transactions in debt and equity markets" [4].

The major role of a bank within China is to provide loans to corporates and households. A high share of the loans indicates low substitutability of the bank and will have a negative impact on economy if it is difficult to find an alternative source of funding [3]. Therefore, we include two indicators within the category "personal loans and advances" and "corporate loans and advances" (corporate loans and advances do not include discounted bills. The figures for the indicator are adjusted to ensure all the banks do not include discounted bills for consistency).

Complexity. This dimension of systemic importance is regarding to the "too-complex-to-fail" theory [29]. The logic behind the category is that more complex bank is more difficult to dissolve in case of a failure as greater costs and time are needed [4]. The official BCBS approach includes three indicators in the category "OTC derivatives notional value," "level 3 assets," and "held for trading and available for sale" with equal weights.

Due to absence of OTC derivative market and data availability in China, we include three indicators in the category of "complexity": "derivative financial assets," "held for trading," and "available for sale." Among them, "held for trading" and "available for sale" are distinguished to ensure data consistency among the banks (if the bank reports "held for trading" and "available for sale" together in investment securities, details can be found in the note).

Public Confidence. This is the category that we did major modification on.

The official BCBS measurement approach focuses on the banks' footprints worldwide to capture their global impact. The two indicators: cross-jurisdictional claims and crossjurisdictional liabilities measure the bank's activities outside its headquarters to describe how much is the international impact from its distress or failure [4]. The idea behind the indicator is that the greater global reach of a bank, the more widespread the spillover effect from its failure.

Different from BCBS approach, our objective is to identify the systemically important banks within China rather than worldwide. Therefore, a proxy to emphasize the domestic importance of a bank should be replaced with the category. As with the last category of systemic importance proposed by Braemer and Gischer [3], we also adopt "public confidence" to capture the public perception of the domestic impact that will be after a bank's failure. The more deposits from household of a bank are at risk, the more likely worriedness about financial instability is to spread over the whole nation. Accordingly, the bank is more likely to cause a systemic event that bank runs spread over the banking system. Hence, under the category of "public confidence," "deposit from household" which is the sum of demand deposit and time deposit is used as the measure.

The choice of indicators relies on the assessment objective, real situation, and also data availability. We present an overview of difference and linkage between official BCBS assessment methodology for G-SIBs, measurement method for Australian D-SIBs, and our measurement approach for Chinese D-SIB in Table 1.

One thing that should be noticed is that there exists inconsistency of accounts in financial statements among the banks. Therefore, we double check the original figures from financial statements and adjust them into a general framework of accounts under Generally Accepted Accounting Principles (GAAP) to ensure that all the indicators we use convey the same implications among the samples. Table 15 shows the main difference of accounts and the adjustments we did.

3.1.2. Weights and Scores. The five categories of the indicators describe a bank's systemic importance from different distinct dimensions. As with the official BCBS approach, all the five categories will have the equal weight: $20 \%$, under our methodology.

As for indicators within one category, all the indicators have equal weights under the official BCBS approach as well as assessment method for Australian D-SIBs. However, to emphasize the different role that each indicator plays in distinguishing banks, we proposed an entropy-based method to determine the weights. We want to design the weighting method, which puts more weights on the indicators in which the samples distribute more dispersedly. That means that if the indicator is better to differentiate the banks it should have more weights. Also, this weighting method ensures weight update every year, which captures the changing importance of the indicators.

For a category with more than one indicator, suppose each bank $i$ has its value $X_{i j}$ on indicator $j$. The entropy of indicator $j$ is defined as in the following equation:

$$
e_{j}=-\frac{\sum_{i=1}^{n} P_{i j} \ln P_{i j}}{\ln (n)},
$$

where $P_{i j}=\left(X_{i j} / \sum_{i=1}^{n} X_{i j}\right)$ and the total number of banks is $n$.

The greater difference of indicator value among the banks, the smaller entropy of the indicator. And that means that the indicator plays a more important role to differentiate the banks. Therefore, we define difference coefficient as follows to weight the indicator:

$$
g_{j}=1-e_{j} .
$$

Then we do normalization as in (3) to ensure that the sum of indicators' weights within one category is 1 , where $m$ indicators in total are assumed. Then the weight of indicator $j$ within the category is determined as $W_{j}$,

$$
W_{j}=\frac{g_{j}}{\sum_{j=1}^{m} g_{j}} .
$$


TABLE 1: Indicators of assessment approaches for G-SIBs and D-SIBs.

\begin{tabular}{|c|c|c|c|}
\hline \multirow{2}{*}{$\begin{array}{l}\text { Category } \\
\text { (and weights) }\end{array}$} & \multicolumn{3}{|c|}{ Individual indicator } \\
\hline & BCBS approach (G-SIBs) & Approach for Australia (D-SIBs) & Approach for China (D-SIBs) \\
\hline Size $(20 \%)$ & $\begin{array}{l}\text { Total exposures as defined for use in } \\
\text { the Basel III leverage ratio }\end{array}$ & Total residence assets & Total assets (on balance) \\
\hline $\begin{array}{l}\text { Interconnectedness } \\
(20 \%)\end{array}$ & $\begin{array}{l}\text { (i) Intrafinancial system assets } \\
\text { (ii) Intrafinancial system liabilities } \\
\text { (iii) Wholesale funding ratio }\end{array}$ & $\begin{array}{l}\text { (i) Loans to financial corporations } \\
\text { (ii) Deposits from financial } \\
\text { corporations }\end{array}$ & $\begin{array}{l}\text { (i) Intrafinancial system assets } \\
\text { (ii) Intrafinancial system liabilities }\end{array}$ \\
\hline $\begin{array}{l}\text { Nonsubstitutability } \\
(20 \%)\end{array}$ & $\begin{array}{l}\text { (i) Assets under custody } \\
\text { (ii) Payment cleared and settled } \\
\text { through payment systems } \\
\text { (iii) Values of underwritten } \\
\text { transactions in debt and equity } \\
\text { markets }\end{array}$ & $\begin{array}{l}\text { (i) Loans to households } \\
\text { (ii) Loans to nonfinancial } \\
\text { corporations } \\
\text { (iii) Loans to the general } \\
\text { government } \\
\text { (iv) Loans to community service } \\
\text { and nonprofit organizations }\end{array}$ & $\begin{array}{l}\text { (i) Personal loans and advances } \\
\text { (ii) Corporate loans and advances }\end{array}$ \\
\hline Complexity (20\%) & $\begin{array}{l}\text { (i) OTC derivatives notional value } \\
\text { (ii) Level } 3 \text { assets } \\
\text { (iii) Held for trading and available } \\
\text { for sale }\end{array}$ & $\begin{array}{l}\text { (i) Investment securities } \\
\text { (ii) Trading securities }\end{array}$ & $\begin{array}{l}\text { (i) Held for trading* } \\
\text { (ii) Available for sale } \\
\text { (iii) Derivative financial assets }\end{array}$ \\
\hline $\begin{array}{l}\text { Cross-jurisdictional } \\
\text { activity }(20 \%)\end{array}$ & $\begin{array}{l}\text { (i) Cross-jurisdictional claims } \\
\text { (ii) Cross-jurisdictional liabilities }\end{array}$ & Not included & Not included \\
\hline $\begin{array}{l}\text { Public confidence }^{* *} \\
(20 \%)\end{array}$ & Not included & Deposits from households & Deposits from households \\
\hline
\end{tabular}

* Including designated at fair value through profit or loss.

** "Public confidence" is called "domestic sentiment" in measurement approach for Australia D-SIBs.

The score on each indicator is calculated in a way that is identical with the official BCBS approach to capture the relative systemic importance among the sample. That is to divide individual bank amount by the aggregate amount across all the banks in the sample. The score is then weighted by the indicator's weight, respectively. The final score of systemic importance comes with all the weighted scores on all the indicators (there are nine indicators under our measurement approach) added.

3.2. Copula Approach. Besides identification of Chinese $\mathrm{D}$-SIBs under the indicator-based measurement approach presented in Section 3.1, another goal of the paper is to empirically investigate whether there are contagion effects from D-SIBs to the rest of the banking system during the recent major financial crises, which will also provide ancillary evidence for the previous judgment of D-SIBs.

What are the dependence structures between D-SIBs and the rest of banks before and after the crises? Is there a tendency of strengthened distress correlations with D-SIBs after the crises? To answer these questions, the nonlinear model-Copula-provides a powerful tool for this analysis, which will be introduced in Section 3.2.1. In Section 3.2.2, we demonstrate how Clayton Copula which is asymmetric measures the lower tail dependence. Two major recent financial crises-subprime crisis and European debt crisisare used for event study.

3.2.1. Basic Concept of Copula. A Copula function is a function that joins multivariate distribution functions to their one-dimensional margins; therefore, it is called a link function [30]. For given univariate marginal distribution functions $F_{1}\left(x_{1}\right), F_{2}\left(x_{2}\right), \ldots, F_{m}\left(x_{m}\right)$ of variables $x_{1}, x_{2}, \ldots, x_{m}$, the multivariate distribution function $C$ is defined as a Copula function in the following equation [17]:

$$
C\left(F_{1}\left(x_{1}\right), F_{2}\left(x_{2}\right), \ldots, F_{m}\left(x_{m}\right)\right)=F\left(x_{1}, x_{2}, \ldots, x_{m}\right) .
$$

Sklar [31] proved that a Copula function has the following property: If $F\left(x_{1}, x_{2}, \ldots, x_{m}\right)$ is a joint multivariate distribution function with univariate marginal distribution functions $F_{1}\left(x_{1}\right), F_{2}\left(x_{2}\right), \ldots, F_{m}\left(x_{m}\right)$, then there exists a Copula function $C\left(u_{1}, u_{2}, \ldots, u_{m}\right)$ that $F\left(x_{1}, x_{2}, \ldots, x_{m}\right)=$ $C\left(F_{1}\left(x_{1}\right), F_{2}\left(x_{2}\right), \ldots, F_{m}\left(x_{m}\right)\right)$ holds. If each $F_{i}$ is continuous then $C$ is unique. Hence, Copula functions provide a unifying and flexible way to study multivariate distributions [32]. In recent years, Copula functions have been widely used in financial modeling [33, 34]. Applications of Copula functions in finance range from capital allocation $[35,36]$, financial markets contagion [37-40], and risk integration [41-43] to default correlations [44].

The commonly used Copula functions are Gaussian Copula, Student's Copula ( $t$-Copula), which are symmetric, and Archimedean family of Copulas [45], with their definitions presented as in Table 2.

3.2.2. Measurement of Contagion Effects. To investigate the contagion effects between the banks, our focus is on the lower tail dependence. That means that we attempt to explore how much is the probability that the other banks also fall in the extremely bad situation when one bank is in its worst 
TABLE 2: Commonly used Copula functions.

\begin{tabular}{|c|c|c|}
\hline Copula & $C\left(u_{1}, u_{2}, \ldots, u_{N}\right)$ & Note [17] \\
\hline $\begin{array}{l}\text { Gaussian } \\
\text { Copula }\end{array}$ & $C\left(u_{1}, u_{2}, \ldots, u_{N} ; \rho\right)=\Phi_{\rho}\left(\Phi^{-1}\left(u_{1}\right), \Phi^{-1}\left(u_{2}\right), \ldots, \Phi^{-1}\left(u_{N}\right)\right)$ & $\begin{array}{l}\rho \text { is a symmetric, positive definite } \\
\text { matrix with diag } \rho=1 ; \Phi_{\rho} \text { is the } \\
\text { standardized multivariate normal } \\
\text { distribution with correlation } \\
\text { matrix } \rho \text {. }\end{array}$ \\
\hline T-Copula & $C\left(u_{1}, u_{2}, \ldots, u_{N} ; \rho, k\right)=t_{\rho, k}\left(t_{k}^{-1}\left(u_{1}\right), t_{k}^{-1}\left(u_{2}\right), \ldots, t_{k}^{-1}\left(u_{N}\right)\right)$ & $\begin{array}{l}\rho \text { is a symmetric, positive definite } \\
\text { matrix with diag } \rho=1 ; t_{\rho, k} \text { is the } \\
\text { standardized multivariate } \\
\text { Student's distribution with } k \\
\text { degrees of freedom and } \\
\text { correlation matrix } \rho \text {. }\end{array}$ \\
\hline $\begin{array}{l}\text { Archimedean } \\
\text { family of } \\
\text { Copulas }\end{array}$ & $C\left(u_{1}, u_{2}, \ldots, u_{N}\right)= \begin{cases}\varphi^{-1}\left[\varphi\left(u_{1}\right)+\varphi\left(u_{2}\right)+\cdots+\varphi\left(u_{N}\right)\right], & \text { if } \sum_{i=1}^{N} \varphi\left(u_{i}\right) \leq \varphi(0) \\
0, & \text { otherwise }\end{cases}$ & $\begin{array}{l}\varphi(u) \text { is the generator of the } \\
\text { Copula. It is a function that } \\
\text { satisfies } \varphi(1)=0, \varphi^{\prime}(u)<0 \text {, and } \\
\varphi^{\prime \prime}(u)>0 \text {, for all } 0 \leq u \leq 1\end{array}$ \\
\hline
\end{tabular}

situation. To express the conditional probability sense in a mathematical way, we have the following equation to define the lower tail-dependence coefficient [46]:

$$
\lambda^{\mathrm{lo}}=\lim _{u \rightarrow 0} P\left\{Y<G^{-1}(u) \mid X<F^{-1}(u)\right\}
$$

where $F(x)$ and $G(y)$ are the marginal distributions of random variables $X$ and $Y$ and $G^{-1}(u)$ and $F^{-1}(u)$ are the inverse distribution functions of $X$ and $Y$, respectively.

An equivalent definition of lower tail dependence in terms of a bivariate Copula function is given in the following equation:

$$
\lambda^{\mathrm{lo}}=\lim _{u \rightarrow 0} \frac{C(u, u)}{u}
$$

Gaussian Copula and Student's Copula are symmetric in their tails, while the real world is not always the case. Archimedean family of Copulas, which is also extensively applied, does have some typical distributions, to better capture the asymmetric tail-dependence structure. Among Archimedean family of Copulas, the most popular functions are Gumbel Copula, Clayton Copula, and Frank Copula. We present bivariate distribution of the three Archimedean Copulas, as well as their generators and tail-dependence coefficients in Table 3.

Frank Copula also has symmetric tail dependence as with Gaussian Copula and $t$-Copula, while Gumbel Copula and Clayton Copula are more flexible to describe the different dependence structure on the tails. Clayton Copula is sensitive to the changes of lower tail dependence and provides us with a useful measure to calculate to what extent two banks correlate when they are simultaneously in extremely bad situations. Therefore, we choose Clayton Copula to model the correlations between D-SIBs and the other banks.

Our analysis splits into two parts concerning the two financial crises, respectively. The first part is about the contagion effects during the subprime crisis. And the second part is about the contagion effects during the European debt crisis.
Closing prices of every trading day for all the 16 listed commercial banks are used. Daily return rate of each bank at time $t$ is then calculated as in the following equation:

$$
\text { return }_{t}=\ln \frac{\text { closeprice }_{t}}{\text { closeprice }_{t-1}} .
$$

Pairs of two, one from D-SIBs and the other from the rest of the banks, are formed, respectively. Then we use Clayton Copula to model daily return correlations of the two banks both before and after the crises and estimate the parameter. We focus on the change of lower tail-dependence coefficients before and after the crises.

Besides the analysis between individual D-SIB and nonD-SIB in pairs of two, we also consider D-SIBs as a whole subsystem, to eliminate the mutual correlations among DSIBs. Then the rest of the banks are examined one by one with the D-SIB subsystem by the same procedure.

The main issue here is to construct a series of daily return rate of the D-SIB subsystem. The return rate series of the DSIB subsystem is the weighted average of daily return rates of individual D-SIBs that are included in the subsystem, where the weights are the relative market value of these banks at the end of last year as shown in the following equation:

$$
\text { return }_{\text {subsystem }}=\sum_{i=1}^{n} \frac{\text { marketvalue }_{i}}{\sum_{i=1}^{n} \text { marketvalue }_{i}} \text { return }_{i} .
$$

Note that the market value which is used as weight is the figure reported at the end of last year. That means that, to construct the weighted average series, weights are updated every year, while the series also is updated in daily frequency.

3.3. Data Description. At the end of the year 2012, China's banking sector consisted of two policy banks and China Development Bank, 5 large commercial banks, 12 joint-stock commercial banks, 144 city commercial banks, 337 rural commercial banks, and so forth. Overall, the number of banking institutions in China's banking system amounted to 3747 [47]. 
TABLE 3: Archimedean family of Copulas.

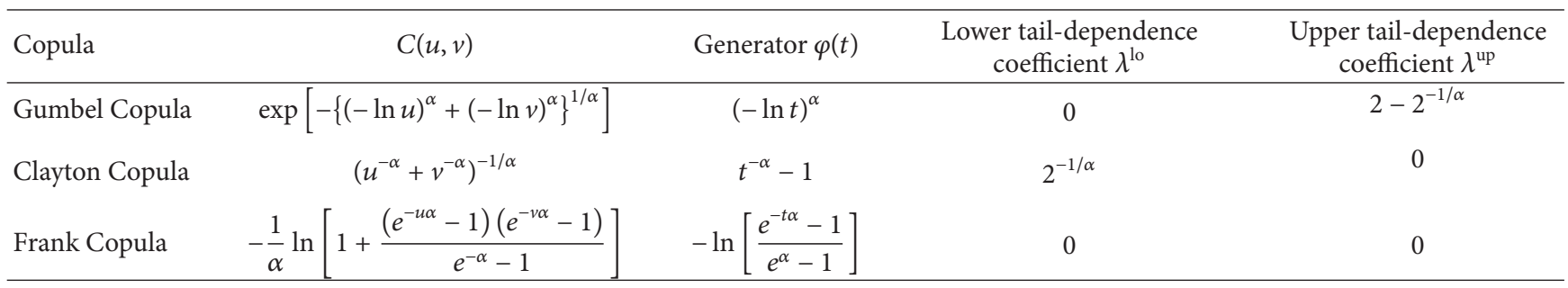

Although the number of banking institutions is large, a small group of them dominates the entire market. Due to data availability but also the nonsubstitutable roles they play, we focus on all the 16 Chinese listed commercial banks which are potential D-SIBs in nature. The publicly traded banks include all the 5 large commercial banks (Industrial and Commercial Bank of China (ICBC), Agricultural Bank of China (ABC), Bank of China (BOC), China Construction Bank (CCB), and Bank of Communications (BOCOM)), 8 of 12 joint-stock commercial banks (China Merchants Bank (CMB), Shanghai Pudong Development Bank (SPDB), China Minsheng Banking Corporation (CMBC), China Citic Bank (CITIC), China Everbright Bank (CEBB), Industrial Bank Corporation (IBC), Huaxia Bank (HXB), and Shenzhen Development Bank (SDB, now is merged with Pingan Bank)), and also 3 city commercial banks (Bank of Beijing (BBJ), Bank of Nanjing (BNJ), and Bank of Ningbo (BNB)). According to 2012 annual report of China Banking Regulatory Commission (CBRC) and our estimates from annual reports of all the listed banks, the 16 banks take a large asset proportion, around $62 \%$ of the whole banking sector; therefore they are reliable to represent the industry (2012 annual report of CBRC stated that large commercial banks include ICBC, ABC, BOC, CCB, and BOCOM own $44.93 \%$ assets of the whole banking sector. Upon all the end-2012 figures of assets of the 16 listed commercial banks, we estimated that their assets take around $61.5 \%$ of the whole industry).

These listed commercial banks began to adopt new accounting standards in 2007. After the year of 2007, Chinese banking sector has been developing stably without significant reforms. This period also covers the before/after time of major recent financial crises: subprime crisis and European debt crisis. We choose the time period of 2007-2012 to gather and organize our data for analysis.

Under the indicator-based measurement approach to identify Chinese D-SIBs, figures on all the indicators which are presented in Table 1 are gathered from Wind database (Wind database is a widely used data service provider in China. It provides data from annual reports and footnotes from listed companies, data in report released by governments such as National Bureau of Statistics, China Banking Regulatory Commission, and also stock market prices and trading volumes from exchanges). Most of them are originally from annual financial statements and their notes of the 16 listed commercial banks while some items are from the regulatory agency-CBRC. We also double check them with the original sources.
For Copula approach for modeling the dependence structure, we prepare daily closing prices of the 16 listed banks during the identical time period, as well as the market values at the end of each year. They are also available in Wind database.

\section{Quantitative Results}

4.1. Systemic Importance Distribution and Changes. This part presents our analysis for the systemic importance of all the banks covered in the sample, using the indicator-based measurement approach. While the list of D-SIBs might be obvious, we intend to highlight the relative distribution of systemic importance, as well as the change of the results during the years.

Our quantitative calculation of systemic importance in the Chinese banking system validates the public perception. Due to the final scores, the 16 listed commercial banks perform differently from the five dimensions of systemic importance.

We firstly present the current levels of systemic risk in the Chinese banking system using the end-2012 figures. As Table 4 shows, the "Big Four" major banks ("Big Four" major banks include Industrial and Commercial Bank of China (ICBC), Agricultural Bank of China (ABC), Bank of China (BOC), and China Construction Bank (CCB)), or "Big Five" major banks ("Big Five" major banks are the same as 5 large commercial banks, which include Industrial and Commercial Bank of China (ICBC), Agricultural Bank of China (ABC), Bank of China (BOC), China Construction Bank (CCB), and Bank of Communications (BOCOM)) (which is called large commercial banks under $\mathrm{CBRC}$ regulation) process high systemic impact on the banking system. The "Big Four" take $67.1 \%$ and the "Big Five" account for $73 \%$ systemic importance of the total system. Our result demonstrates that the biggest systemic risk originates from Industrial and Commercial Bank of China (ICBC) with 20\% of the system, with Bank of China (BOC) followed with $16.8 \%$. Also in 2011, BOC followed ICBC and ranked number 2 in domestic systemic importance in Chinese banking sector (see Table 16). However, ICBC has not been in the list of global systemic important banks until this year. It is BOC that remains in the list for three years. That means global systemic importance does not equal domestic systemic importance. It is the range systemic importance covers that matter.

We can also find that, BOC is smallest in "Size" and "Public Confidence" measured by deposit from households 
TABLE 4: Domestic systemic importance of Chinese banks at 2012.

\begin{tabular}{|c|c|c|c|c|c|c|c|}
\hline Ranking & Bank & Size & Interconnectedness & Nonsubstitutability & Complexity & Public confidence & Final score \\
\hline 1 & $\begin{array}{l}\text { Industrial and } \\
\text { Commercial Bank of } \\
\text { China }\end{array}$ & 0.2042 & 0.1274 & 0.2022 & 0.2192 & 0.2466 & 0.1999 \\
\hline 2 & Bank of China & 0.1476 & 0.1319 & 0.1604 & 0.2465 & 0.1508 & 0.1675 \\
\hline 3 & $\begin{array}{l}\text { Agricultural Bank of } \\
\text { China }\end{array}$ & 0.1542 & 0.1001 & 0.1492 & 0.1458 & 0.2416 & 0.1582 \\
\hline 4 & $\begin{array}{l}\text { China Construction } \\
\text { Bank }\end{array}$ & 0.1627 & 0.0943 & 0.1751 & 0.1032 & 0.1931 & 0.1457 \\
\hline 5 & $\begin{array}{l}\text { Bank of } \\
\text { Communications }\end{array}$ & 0.0614 & 0.0639 & 0.0626 & 0.0611 & 0.0451 & 0.0588 \\
\hline 6 & $\begin{array}{l}\text { Industrial Bank } \\
\text { Corporation }\end{array}$ & 0.0378 & 0.1027 & 0.0278 & 0.0343 & 0.0113 & 0.0428 \\
\hline 7 & $\begin{array}{l}\text { China Merchants } \\
\text { Bank }\end{array}$ & 0.0397 & 0.0450 & 0.0492 & 0.0349 & 0.0348 & 0.0407 \\
\hline 8 & $\begin{array}{l}\text { China Minsheng } \\
\text { Banking Corporation }\end{array}$ & 0.0374 & 0.0871 & 0.0352 & 0.0241 & 0.0148 & 0.0397 \\
\hline 9 & $\begin{array}{l}\text { Shanghai Pudong } \\
\text { Development Bank }\end{array}$ & 0.0366 & 0.0588 & 0.0308 & 0.0203 & 0.0147 & 0.0323 \\
\hline 10 & China Citic Bank & 0.0345 & 0.0381 & 0.0346 & 0.0339 & 0.0155 & 0.0313 \\
\hline 11 & $\begin{array}{l}\text { China Everbright } \\
\text { Bank }\end{array}$ & 0.0265 & 0.0455 & 0.0250 & 0.0264 & 0.0107 & 0.0268 \\
\hline 12 & $\begin{array}{l}\text { Shenzhen } \\
\text { Development Bank }\end{array}$ & 0.0187 & 0.0346 & 0.0178 & 0.0107 & 0.0065 & 0.0177 \\
\hline 13 & Huaxia Bank & 0.0173 & 0.0313 & 0.0141 & 0.0084 & 0.0061 & 0.0154 \\
\hline 14 & Bank of Beijing & 0.0130 & 0.0231 & 0.0102 & 0.0081 & 0.0053 & 0.0119 \\
\hline 15 & Bank of Ningbo & 0.0043 & 0.0087 & 0.0032 & 0.0186 & 0.0018 & 0.0073 \\
\hline 16 & Bank of Nanjing & 0.0040 & 0.0075 & 0.0025 & 0.0044 & 0.0014 & 0.0040 \\
\hline
\end{tabular}

among the "Big Four" banks, which may result from its branches being in limited number. However, due to its highest score in "interconnectedness" and "complexity" category, it still demonstrated itself as the second systemically important bank within the nation, over Agricultural Bank of China $(\mathrm{ABC})$ and China Construction Bank (CCB). Therefore, it is important to note the "Size" category. Although commonly utilized and may closely relate to other categories, it is still not an adequate proxy of systemic risk, as it cannot detect such disparities. "Too-complex-to-fail" is as important as "too-bigto-fail" problem as the phenomenon suggests.

Another bank to note is BOCOM. Although we note "Big Five" major banks, and put BOCOM together with "Big Four" major banks, a large difference between BOCOM and "Big Four" major banks can be observed both in total scores and scores within categories. CCB, which ranks the last in 2012 final score among the "Big Four" major banks, is almost 2.5 times systemic important of BOCOM, although the gaps in "complexity" and "interconnectedness" categories are not that large. BOCOM also has no overlaps in scores with other jointstock commercial banks in the years, seemingly independent of that system. Therefore, we argue that it is not so fair if we put BOCOM into the same bucket as "Big Four" banks and mandate it to hold the identical additional capital. Although, it is a natural member of D-SIBs since its impact is more than a little, different bucket from "Big Four" major banks should be considered.

Among the rest, we can observe that city commercial banks such as Bank of Beijing, Bank of Ningbo, and Bank of Nanjing have hardly any systemic relevance with total score under $1.5 \%$. Some joint-stock commercial banks show little domestic systemic importance accounting for less than $2 \%$ of the total, such as Shenzhen Development Bank and Huaxia Bank.

Some other joint-stock commercial banks, however, are much closer to the smallest major bank-Bank of Communications - in their final scores in 2012, which shows the trend to be included in the potential candidates list of D-SIBs. Hence, we suggest that the impact of those banks such as Industrial Bank Corporation (IBC), China Merchants Bank (CMB), and China Minsheng Banking Corporation (CMBC) cannot be neglected. We will also address the issue later regarding to the changes of systemic importance over time.

When we observe the scores in categories of the three banks, an interesting finding is the high rankings of IBC and CMBC in the category of "interconnectedness." IBC, which is characterized with its interbank activities, accounts for more than $10 \%$ systemic importance in the category, ranking the third place. CMBC also lists before BOCOM, one of "Big Five" in the same category. These findings once again 
validated that "Size" only is not adequate to capture systemic importance. At least IBC and CMBC expose themselves too much to the banking system, not consistent with their rankings in the final, which should alert the regulators to tighten their interbank activities.

We demonstrate the final scores of domestic systemic importance over the five-year period in Table 5. The banks are ranked according to the final scores of year 2012.

Focusing on the "Big Four" or "Big Five" major banks, the time series displayed in Figure 1 reveals important information about the levels as well as the changes of domestic systemic importance yearly in the Chinese banking system.

We can find that although the major banks (no matter BOCOM is included or not) still dominate the systemic importance at a high level their domestic systemic importance keeps decreasing sharply during the five years.

The decreasing trend of systemic importance of major banks means domestic systemic importance is distributed among the system more evenly, rather than concentrated on a small group that the regulatory always keeps an eye on. This gives the authorities the implications that more banks with growing systemic importance should also be noticed; otherwise it will be too late to regulate if they become too domestic systemic important.

Figure 2 shows the levels and the changes of domestic systemic importance of joint-stock commercial banks whose final scores are all above 0.02 in the five years.

As for these potential candidates to be included in DSIBs, we suggest that Industrial Bank Corporation, China Merchants Bank, and China Minsheng Banking Corporation should be considered. They are ranking just after the "Big Five" major banks with scores very close to BOCOM in the year 2012.

In addition, IBC's and CMBC's domestic systemic importance demonstrates a tendency of growing over the five years, which are quite different in ways of change from other joint-stock banks as Shanghai Pudong Development Bank (SPDB), China Citic Bank (CITIC), and China Everbright Bank (CEBB), although they were in an almost identical level of systemic importance. Further, IBC and CMBC present significant impacts on the whole banking system from the aspects of "interconnectedness" in 2012, ranking the third and sixth.

As for CMB, it always demonstrates itself as potential systemic important for accounting for around $4 \%$ of the banking system, significantly higher than the rest joint-stock commercial banks. Therefore, we suggest IBC, CMBC, and $\mathrm{CMB}$ to be included in the list of Chinese D-SIBs, while SPDB, CITIC, and CEBB remain in the watch list.

We also follow the official BCBS approach to classify the banks into buckets with additional capital charge while the tentative thresholds differ. According to our suggestions, "Big Four" major banks should be in the top level of the buckets with maximum additional capital requirement, while BOCOM follows behind in the next level. In the current state, besides "Big Five" major banks, the natural members of $\mathrm{D}$ SIBs, potential candidates such as IBC, CMBC, and CMB should also be included, which may provide an incentive to encourage them not to become more systemically important.

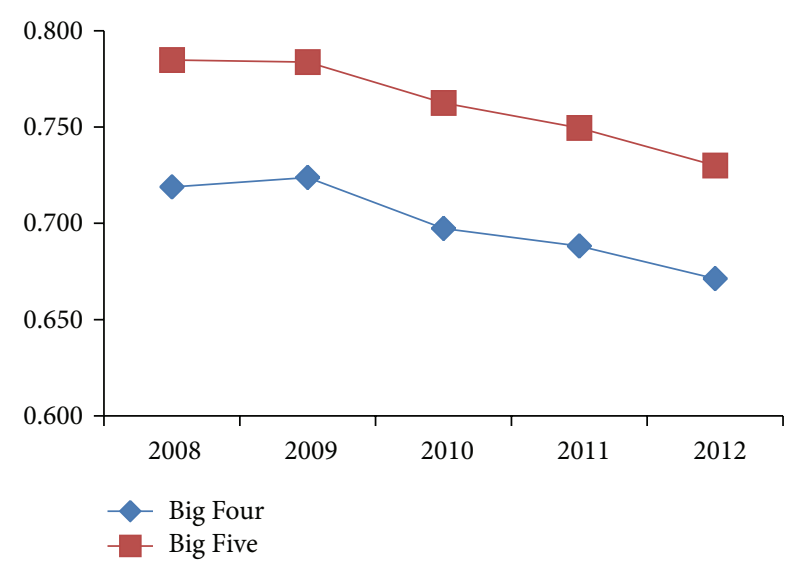

Figure 1: Domestic systemic importance of Chinese major banks.

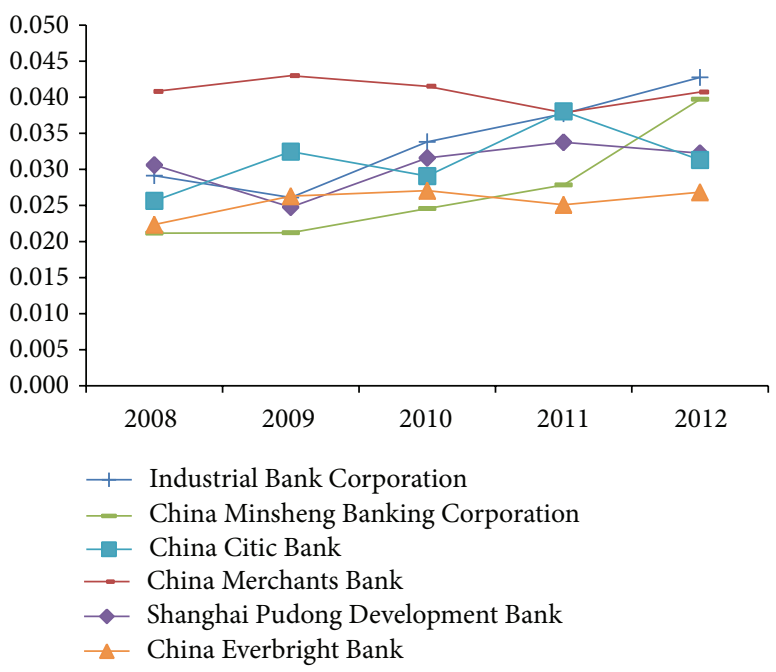

FIGURE 2: Domestic systemic importance of main joint-stock banks.

As for these banks with more than little systemic importance, but not to a degree of potential systemically important, such as SPDB, CITIC, and CEBB, we suggest that the regulatory should also watch their status dynamically. Therefore, a watch list is also recommended. To summarize, the list to be included in each bucket of D-SIBs is then presented as in Table 6 .

4.2. Contagion Effects during Financial Crises. In this part, we present our calculation results for return correlations between D-SIBs and non-D-SIBs under Copula approach. Changes of lower tail dependence structure before and after both the subprime crisis and the European debt crisis are investigated, respectively, as described previously.

4.2.1. Contagion Effects during Subprime Crisis. The global impact of this crisis strengthened significantly after September 19, 2008. Specific actions to lower interest rates were taken by central banks of various countries in the west. In October 9, 2008, following western countries, South Korea, 
TABLE 5: Final scores of domestic systemic importance over 2008-2012.

\begin{tabular}{|c|c|c|c|c|c|}
\hline Banks & 2008 & 2009 & 2010 & 2011 & 2012 \\
\hline Industrial and Commercial Bank of China & 0.1915 & 0.1913 & 0.1891 & 0.2071 & 0.1999 \\
\hline Bank of China & 0.2167 & 0.1964 & 0.2008 & 0.1811 & 0.1675 \\
\hline Agricultural Bank of China & 0.1523 & 0.1721 & 0.1591 & 0.1530 & 0.1582 \\
\hline China Construction Bank & 0.1584 & 0.1640 & 0.1484 & 0.1469 & 0.1457 \\
\hline Bank of Communications & 0.0660 & 0.0599 & 0.0652 & 0.0614 & 0.0588 \\
\hline Industrial Bank Corporation & 0.0291 & 0.0261 & 0.0338 & 0.0377 & 0.0428 \\
\hline China Merchants Bank & 0.0408 & 0.0430 & 0.0415 & 0.0379 & 0.0407 \\
\hline China Minsheng Banking Corporation & 0.0212 & 0.0212 & 0.0246 & 0.0278 & 0.0397 \\
\hline Shanghai Pudong Development Bank & 0.0306 & 0.0248 & 0.0316 & 0.0338 & 0.0323 \\
\hline China Citic Bank & 0.0256 & 0.0325 & 0.0291 & 0.0381 & 0.0313 \\
\hline China Everbright Bank & 0.0223 & 0.0263 & 0.0270 & 0.0251 & 0.0268 \\
\hline Shenzhen Development Bank & 0.0110 & 0.0095 & 0.0099 & 0.0133 & 0.0177 \\
\hline Huaxia Bank & 0.0176 & 0.0152 & 0.0145 & 0.0147 & 0.0154 \\
\hline Bank of Beijing & 0.0115 & 0.0096 & 0.0134 & 0.0129 & 0.0119 \\
\hline Bank of Ningbo & 0.0025 & 0.0040 & 0.0067 & 0.0047 & 0.0073 \\
\hline Bank of Nanjing & 0.0029 & 0.0040 & 0.0052 & 0.0045 & 0.0040 \\
\hline "Big Four" & 0.7189 & 0.7238 & 0.6973 & 0.6882 & 0.6712 \\
\hline "Big Five" & 0.7849 & 0.7838 & 0.7626 & 0.7496 & 0.7300 \\
\hline
\end{tabular}

TABLE 6: Buckets of Chinese D-SIBs.

\begin{tabular}{ll}
\hline Bucket & Bank list \\
\hline \multirow{3}{*}{ A } & $\begin{array}{l}\text { Industrial and Commercial Bank of China } \\
\text { Bank of China } \\
\text { Agricultural Bank of China } \\
\text { China Construction Bank }\end{array}$ \\
\hline B & Bank of Communications \\
C & $\begin{array}{l}\text { Industrial Bank Corporation } \\
\text { China Merchants Bank } \\
\text { China Minsheng Banking Corporation }\end{array}$ \\
\hline & Shanghai Pudong Development Bank \\
Watch list & China Citic Bank \\
& China Everbright Bank
\end{tabular}

Japan, Hong Kong, Taiwan, and other relevant authorities were taking measures to ease monetary policy and inject capital to the banks. We set the date that this subprime crisis begins to influence the Chinese banking system as October 9, 2008. One year before the date is the precrisis period, while one year after the date is the postcrisis period. To make it more specific, we present the details of time spans in Table 7.

At that time, $\mathrm{ABC}$ and $\mathrm{CEBB}$ were not publicly traded, so there were no daily closing prices available for the two banks. Hence, our analysis in this part omits the two banks.

In 2008 and 2009, the "Big Five" accounted for almost $80 \%$ systemic importance of the banking system. Our analysis will view "Big Five" (without $\mathrm{ABC}$ ) as a whole D-SIBs subsystem since other banks' relevance was still limited compared with that under the current state.

The weights to calculate 2007 daily returns of the subsystem are not using the market values of end-2006 because too many banks were not listed before 2007 (only seven banks including SDB, SPDB, HXB, CMBC, CMB, ICBC, and BOC were listed commercial banks before 2007). Therefore, we use market values of end-2007 instead, to weight the daily returns of 2007. 2008 and 2009 daily return series of the subsystem is the weighted average of individual banks' daily return. The weights are the relative market value of end-2007 and end2008, respectively.

We use Clayton Copula to model the daily return correlations between D-SIBs and non-D-SIBs in pairs of two as described in Section 3.2.2. To make the process clearer, we take Bank of China (BOC), a supposed D-SIB, and Shanghai Pudong Development Bank (SPDB), one of the rest of the banks, as example to illustrate.

Firstly, for the period before the subprime crisis, we estimate the marginal distributions of daily return for both BOC and SPDB, as Figures 3, 4, 5, and 6 show. Nonparameter methods-both empirical distribution estimation method and kernel smoothing estimation method-are used. Then, we use Clayton Copula to model the joint distribution of daily return rates of BOC and SPDB. Figures 7 and 8 depict the Clayton Copula cumulative distribution function and probability density function, respectively. Parameter $\alpha$ to determine the Copula function is estimated 1.3039; therefore, we calculate the lower tail-dependence coefficient $\lambda^{\text {lo }}=$ $2^{-1 / \alpha}=0.5877$.

Similarly, as with the case after the period after the subprime crisis, we also estimate the marginal distributions of daily return rates for both the banks and use Clayton Copula to model the joint distribution. Parameter $\alpha$ is estimated 1.7794, and therefore lower tail-dependence coefficient is $\lambda^{\mathrm{lo}}=2^{-1 / \alpha}=0.6774$.

By comparing the lower tail-dependence coefficients before and after the crisis, we find that the correlation 
TABLE 7: Time spans of the subprime crises.

\begin{tabular}{lcc}
\hline Description & Time period & $\begin{array}{c}\text { Number of } \\
\text { trading days }\end{array}$ \\
\hline $\begin{array}{l}\text { Before period of subprime } \\
\text { crisis }\end{array}$ & $20071009-20081009$ & 246 \\
$\begin{array}{l}\text { After period of subprime } \\
\text { crisis }\end{array}$ & $20081010-20091013$ & 246 \\
\hline
\end{tabular}

TABLE 8: Lower tail-dependence coefficients before the subprime crisis.

\begin{tabular}{lccccc}
\hline & ICBC & CCB & BOC & BOCOM & D-SIBs \\
\hline BBJ & 0.699 & 0.733 & 0.684 & 0.712 & 0.749 \\
HXB & 0.692 & 0.692 & 0.635 & 0.710 & 0.716 \\
CMBC & 0.716 & 0.744 & 0.709 & 0.776 & 0.772 \\
BNJ & 0.679 & 0.723 & 0.681 & 0.694 & 0.738 \\
BNB & 0.653 & 0.667 & 0.673 & 0.684 & 0.699 \\
SDB & 0.717 & 0.719 & 0.693 & 0.744 & 0.756 \\
SPDB & 0.665 & 0.681 & 0.588 & 0.698 & 0.697 \\
IBC & 0.697 & 0.677 & 0.627 & 0.695 & 0.711 \\
CMB & 0.740 & 0.728 & 0.662 & 0.762 & 0.756 \\
CITIC & 0.756 & 0.785 & 0.785 & 0.769 & 0.810 \\
\hline
\end{tabular}

TABLE 9: Lower tail-dependence coefficients after the subprime crisis.

\begin{tabular}{lccccc}
\hline & ICBC & CCB & BOC & BOCOM & D-SIBs \\
\hline BBJ & 0.646 & 0.708 & 0.686 & 0.715 & 0.727 \\
HXB & 0.711 & 0.744 & 0.726 & 0.725 & 0.768 \\
CMBC & 0.706 & 0.748 & 0.740 & 0.735 & 0.773 \\
BNJ & 0.691 & 0.735 & 0.718 & 0.703 & 0.755 \\
BNB & 0.748 & 0.783 & 0.766 & 0.709 & 0.804 \\
SDB & 0.603 & 0.720 & 0.653 & 0.700 & 0.707 \\
SPDB & 0.668 & 0.741 & 0.677 & 0.742 & 0.746 \\
IBC & 0.682 & 0.766 & 0.677 & 0.769 & 0.764 \\
CMB & 0.703 & 0.777 & 0.727 & 0.766 & 0.789 \\
CITIC & 0.734 & 0.799 & 0.771 & 0.733 & 0.816 \\
\hline
\end{tabular}

between BOC and SPDB strengthened after the crisis under their bad situations.

Lower tail-dependence coefficients before and after the subprime crisis are calculated. We present the results in Tables 8 and 9. The rows are non-D-SIBs while the columns are DSIBs and the subsystem of D-SIBs.

In general, we can observe high correlations between $\mathrm{D}$ SIBs and non-D-SIBs in their lower tail both before and after the subprime crisis, with most of the coefficients above 0.6. This demonstrates that the individual banks have large probability to fall into the bad situations at the same time, reflecting a huge systemic risk in a whole within the banking system.

Correlations of non-DIBs with ICBC seem lower than these with $\mathrm{BOC}$ and $\mathrm{CCB}$, especially after the subprime crisis. This may be due to ICBC's lower scores in "interconnectedness" and "complexity" categories than the two banks in 2008 and 2009. Although ICBC is largest in total assets and

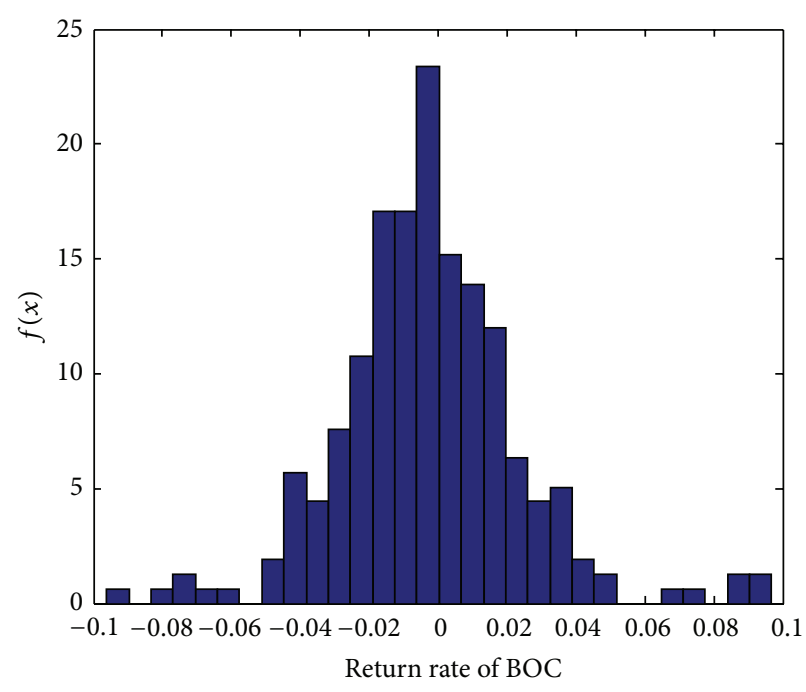

Figure 3: Histogram of return rate of BOC (presubprime).

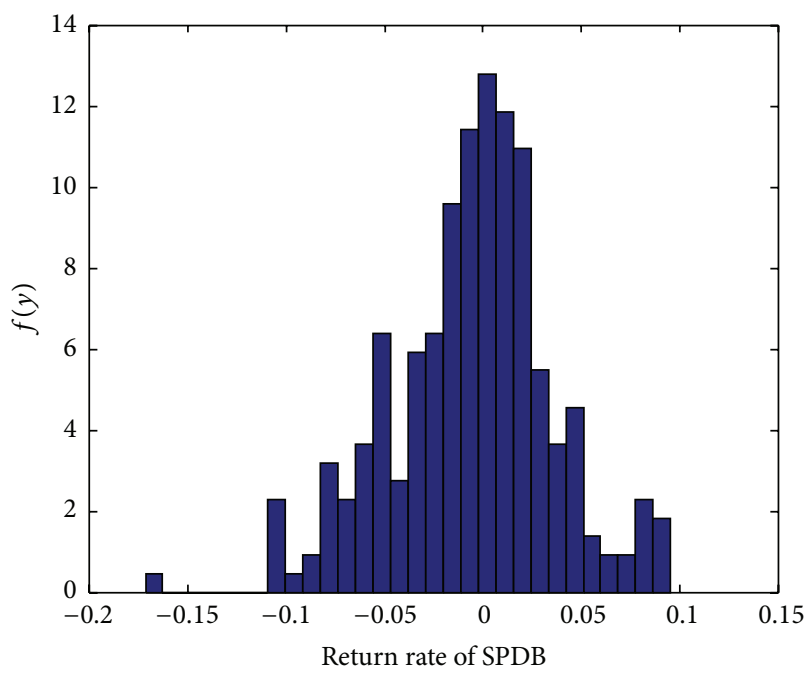

FIgURE 4: Histogram of return rate of SPDB (presubprime).

deposits from households, the result tends to show that ICBC demonstrates limited impact to other non-D-SIBs from the aspects of "interconnectedness" and "complexity", which is consistent with its scores in the two categories.

D-SIBs as a whole subsystem displays stronger correlations with non-D-SIBs than the individual D-SIBs in their lower tails, which reflects that the aggregate impacts of $\mathrm{D}$ SIBs have more widespread impacts than the individuals. This seems to give the authority the implication that "too-manyto-fail" problems are more important to note than individual "too-big-to-fail" or "too-complex-to-fail" problems.

When considering the changes of lower tail-dependence coefficients before and after the subprime crisis, we calculate the percentage change rate by the following equation:

$$
\text { percentage change }=\frac{\lambda_{\text {after }}^{\text {lo }}}{\lambda_{\text {before }}^{\text {lo }}}-1
$$




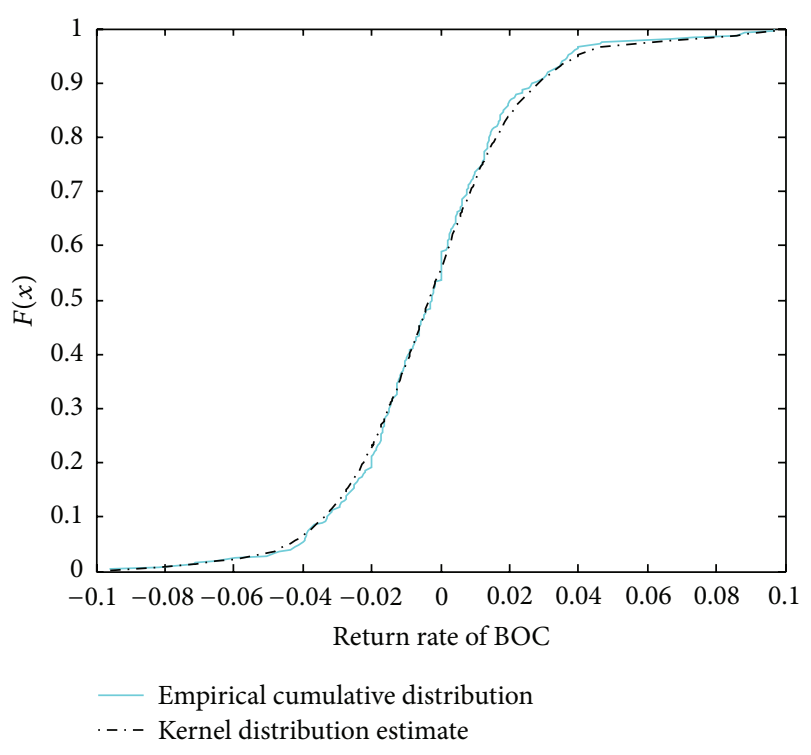

FIGURE 5: Distribution estimate of BOC (presubprime).

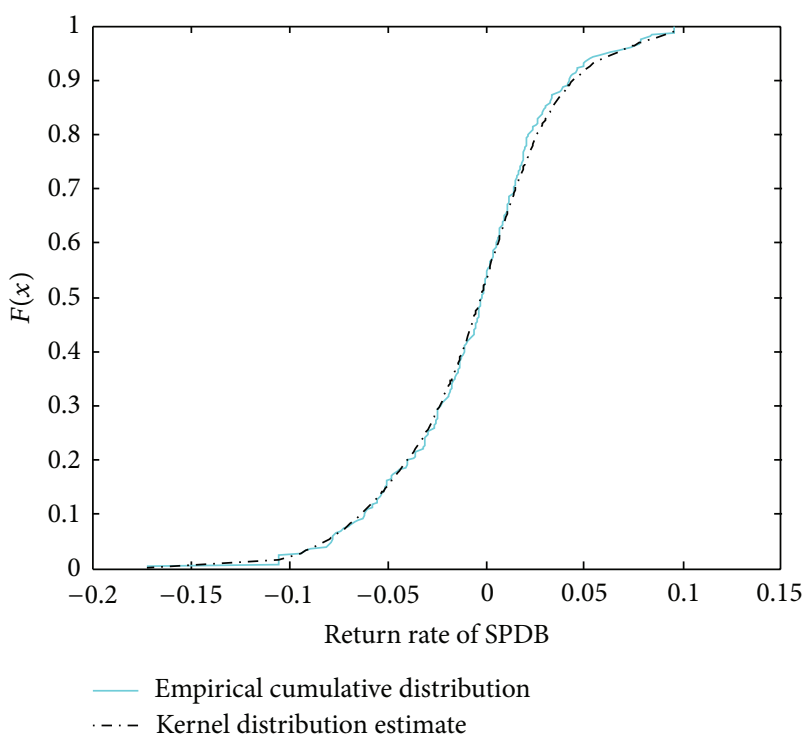

FIGURE 6: Distribution estimate of SPDB (presubprime).

We present the percentage change during the subprime crisis in Table 10. The percentage changes below zero, which means the lower tail correlations weaken during the crisis, are presented in light face font, while the percentages above zero, which demonstrates the strengthened lower tail correlations, are presented in bold font.

In Table 10, we can observe strengthened tail correlations of non-D-SIBs with D-SIBs after subprime crisis in general. When D-SIBs are viewed as a whole, all the non-D-SIBs saw a significant enhanced dependence with it in lower tails, only with exceptions for BBJ and SDB. This is the evidence that there actually existed contagion effects from D-SIBs subsystem to the rest of banking system during this financial crisis.

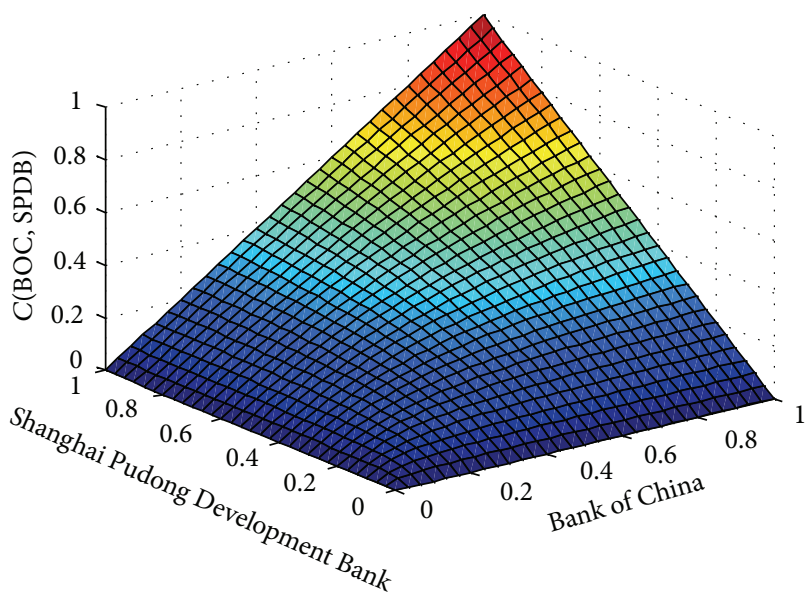

FIGURE 7: Clayton Copula cumulative distribution function (presubprime).

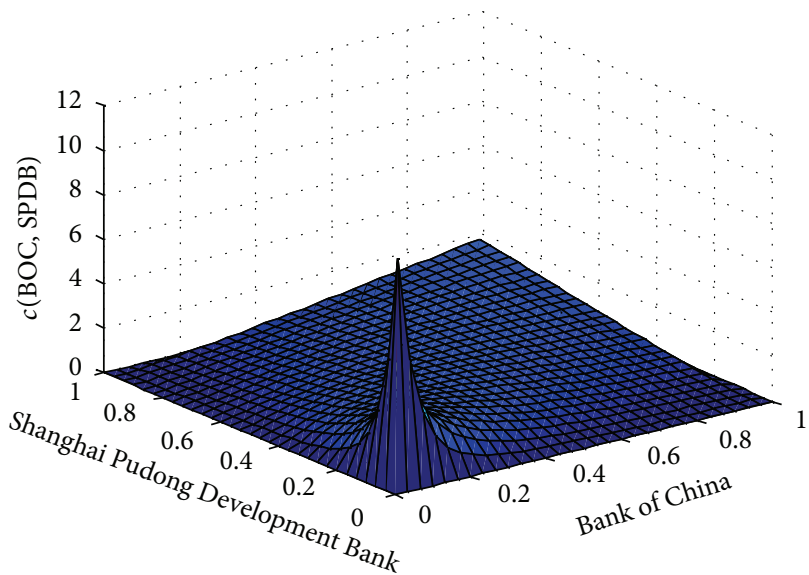

Figure 8: Clayton Copula probability density function (presubprime).

As for BBJ and SDB, which seem not to be affected by D-SIBs, the reason may be that both of them have their major activities in a certain region (Beijing and Shenzhen, in this case), while connections with D-SIBs members are limited. In addition, SDB has weakened relations with almost all the D-SIBs. This may be caused by economy characteristics of Shenzhen, where SDB primarily operates its business. Shenzhen relies heavily on exports; therefore, SDB may be affected by foreign banks abroad rather D-SIBs at home during the crisis.

As with the static analysis for ICBC both before and after the subprime crisis, ICBC also shows not much contagion effects to non-D-SIBs with $60 \%$ of the percentage change of lower tail-dependence coefficients below zero. We continue to argue that, in spite of large size and public confidence, ICBC cannot influence non-D-SIBs to the extent as it ranks in the D-SIBs list, due to its relative loose interconnectedness and low complexity as well. Therefore, it seems that, in a systemic event, Therefore, it seems that, it is not only large banks that contribute much to a systemic risk, but banks with high 
TABLE 10: Changes of lower tail-dependence coefficients (the subprime crisis).

\begin{tabular}{|c|c|c|c|c|c|}
\hline & ICBC & CCB & $\mathrm{BOC}$ & BOCOM & D-SIBs \\
\hline BBJ & $-7.59 \%$ & $-3.47 \%$ & $0.31 \%$ & $0.47 \%$ & $-2.96 \%$ \\
\hline HXB & $2.71 \%$ & $7.58 \%$ & $14.45 \%$ & $2.09 \%$ & $7.22 \%$ \\
\hline CMBC & $-1.52 \%$ & $0.59 \%$ & $4.34 \%$ & $-5.26 \%$ & $0.19 \%$ \\
\hline $\mathrm{BNJ}$ & $1.71 \%$ & $1.64 \%$ & $5.45 \%$ & $1.35 \%$ & $2.36 \%$ \\
\hline BNB & $14.61 \%$ & $17.39 \%$ & $13.88 \%$ & $3.53 \%$ & $15.00 \%$ \\
\hline SDB & $-15.91 \%$ & $0.06 \%$ & $-5.78 \%$ & $-5.96 \%$ & $-6.53 \%$ \\
\hline SPDB & $0.39 \%$ & $8.85 \%$ & $15.26 \%$ & $6.33 \%$ & $7.00 \%$ \\
\hline IBC & $-2.12 \%$ & $13.11 \%$ & $7.91 \%$ & $10.67 \%$ & $7.47 \%$ \\
\hline CMB & $-5.02 \%$ & $6.87 \%$ & $9.79 \%$ & $0.44 \%$ & $4.36 \%$ \\
\hline CITIC & $-2.92 \%$ & $1.74 \%$ & $-1.85 \%$ & $-4.70 \%$ & $0.80 \%$ \\
\hline
\end{tabular}

TABLE 11: Time spans of the European debt crises.

\begin{tabular}{lcc}
\hline Description & Time period & $\begin{array}{c}\text { Number of } \\
\text { trading days }\end{array}$ \\
\hline $\begin{array}{l}\text { Before period of European } \\
\text { debt crisis }\end{array}$ & 20100901-20110901 & 244 \\
$\begin{array}{l}\text { After period of European } \\
\text { debt crisis }\end{array}$ & $20110902-20120904$ & 244 \\
\hline
\end{tabular}

interconnectedness and complexity may also have significant systemic impacts.

4.2.2. Contagion Effects during European Debt Crisis. The contagion effects analysis during European debt crisis follows much similar routine as the analysis of the subprime crisis, while only the time spans and members of D-SIBs and nonD-SIBs differ.

On April 27, 2010, Standard \& Poor's cut Greece main debt rating to $\mathrm{BB}+$ ("junk" status), which increased concerns that the default would occur. Although the impact was not directly related to the banking system, China's export to the Europe grew in a decreasing rate, which yielded a negative impact on the real economy. In August, 2011, the month-to-month growth rate of Chinese exports to EU had decreased to $-2.6 \%$, much lower than the average rate of $5 \%$ since 2000 . We set the date that European debt crisis start its effects on Chinese banking sector as September 1, 2011. Similar with the case in the subprime crisis, one year before the date is the precrisis period, while one year after the date is the postcrisis period, as presented in Table 11.

Time period covered in this part spans from September 1 , 2010 to September 4, 2012. The first 244 trading days compose the precrisis period, while the rest 244 trading days are the postcrisis period. As the time covers three quarters of 2012, we consider both narrow range and wider range of D-SIBs as analyzed in Section 3.1. The narrow range of D-SIBs is "Big Five" major banks, while the wider range also includes IBC, $\mathrm{CMB}$, and $\mathrm{CMBC}$ which are listed in Bucket $\mathrm{C}$ in our proposal. Then we notate them as "Big Five" (Big 5) and "Big Eight" (Big 8), respectively, to view them as two D-SIBs subsystems as a whole.
The weights to calculate 2010 daily returns of the two subsystems are not using the market values of end-2009 due to this data of ABC being not available (ABC began to be publicly traded in July, 2010). Therefore, we use market values of end-2010 instead, to weight the daily returns of 2010. 2011 and 2012 daily return series of the subsystem is the weighted average of daily return rates of individuals included in it. The weights are the relative market value of end-2010 and end2011, respectively.

Clayton Copula is applied to model daily return correlations between D-SIBs and non-D-SIBs in pairs. D-SIBs are used both individually and as a whole. Lower tail-dependence coefficients between D-SIBs and non-D-SIBs are calculated before and after the European debt crisis. We present the results in Tables 12 and 13. The rows are non D-SIBs in the narrow sense while the columns are individual "Big Five" major banks and the two D-SIBs subsystems of "Big Five" and "Big Eight". Since the D-SIBs subsystem "Big Eight" covers IBC, CMB, and CMBC, lower tail-dependence coefficients are not calculated between these three individual banks with the subsystem.

In general, the lower tail-dependence coefficients between non-D-SIBs and D-SIBs are mostly above 0.5 , which still implies possibility of entire banking system's distress. But the lower tail-dependence coefficients are not as high as those during the subprime crisis, which shows decreasing impacts of D-SIBs.

Correlations in tails of non-DIBs with ICBC are also lower than other major banks, especially $\mathrm{ABC}$ and BOC, as with the case during the subprime crisis, again emphasizing the importance of "interconnectedness" and "complexity." Similar finding is that D-SIBs as a whole demonstrates stronger correlations with non-D-SIBs than the individual D-SIBs. Moreover, the "Big 8" subsystem exhibits closer dependence under extreme conditions than "Big 5 " with nonD-SIBs. These findings imply that the total influence of larger D-SIBs subsystem has more domestic reaches within the banking system. Therefore, the regulators should not only focus on individual D-SIBs, but also regard the D-SIBs as a whole to avoid "too-many-to-fail" problems.

We also present the percentage change during the European debt crisis in Table 14. The figures below zero, which implies weaken correlations during the crisis are presented in light face font, while those above zero are in bold font.

In Table 14, by and large, we can observe weakened lower tail correlations of non-D-SIBs with D-SIBs after the European debt crisis. The subsystems, both "Big 5" and "Big 8 ," witness a significant reduced dependence with all the nonD-SIBs in lower tails, only except for SPDB. Moreover, nonD-SIBs also decrease their lower tail correlations with most of the individual D-SIBs.

All the above findings seem to suggest that there are no obvious contagion effects from D-SIBs to the rest of the banks during the European debt crisis. In our point of view, there may be several reasons contributing to this. Firstly, the European debt crisis originated from public sector rather than financial market itself as the case of the subprime crisis, so through indirect channels its impacts on the whole Chinese banking system were limited. Secondly, the period covers 
TABLE 12: Lower tail-dependence coefficients before the European debt crisis.

\begin{tabular}{lllllllr}
\hline & ICBC & CCB & BOCOM & ABC & BOC & Big 5 \\
\hline BBJ & 0.494 & 0.534 & 0.745 & 0.613 & 0.608 & 0.651 & 0.687 \\
CEBB & 0.507 & 0.561 & 0.684 & 0.619 & 0.591 & 0.662 & 0.692 \\
HXB & 0.520 & 0.537 & 0.721 & 0.618 & 0.552 & 0.646 \\
CMBC & 0.511 & 0.527 & 0.704 & 0.593 & 0.583 & 0.646 \\
BNJ & 0.603 & 0.460 & 0.703 & 0.557 & 0.576 & 0.672 & 0.686 \\
BNB & 0.480 & 0.510 & 0.713 & 0.587 & 0.591 & 0.637 \\
SDB & 0.502 & 0.529 & 0.731 & 0.585 & 0.588 & 0.647 & 0.673 \\
SPDB & 0.542 & 0.541 & 0.745 & 0.647 & 0.612 & 0.689 \\
IBC & 0.518 & 0.517 & 0.732 & 0.612 & 0.577 & 0.659 \\
CMB & 0.537 & 0.599 & 0.771 & 0.677 & 0.647 & 0.731 \\
CITIC & 0.506 & 0.495 & 0.697 & 0.631 & 0.615 & 0.712 & 0.643 \\
\hline
\end{tabular}

TABLE 13: Lower tail-dependence coefficients after the European debt crisis.

\begin{tabular}{lccccccc}
\hline & ICBC & CCB & BOCOM & ABC & BOC & Big 5 & Big 8 \\
\hline BBJ & 0.472 & 0.541 & 0.636 & 0.513 & 0.475 & 0.606 & 0.653 \\
CEBB & 0.460 & 0.521 & 0.620 & 0.488 & 0.475 & 0.578 & 0.634 \\
HXB & 0.462 & 0.515 & 0.642 & 0.490 & 0.484 & 0.585 & 0.648 \\
CMBC & 0.473 & 0.493 & 0.548 & 0.436 & 0.437 & 0.552 & - \\
BNJ & 0.395 & 0.470 & 0.511 & 0.427 & 0.413 & 0.502 & 0.555 \\
BNB & 0.342 & 0.446 & 0.579 & 0.401 & 0.401 & 0.488 & 0.550 \\
SDB & 0.520 & 0.614 & 0.709 & 0.537 & 0.532 & 0.658 & 0.712 \\
SPDB & 0.462 & 0.548 & 0.677 & 0.531 & 0.495 & 0.606 & 0.670 \\
IBC & 0.518 & 0.554 & 0.709 & 0.565 & 0.544 & 0.648 & - \\
CMB & 0.453 & 0.512 & 0.633 & 0.490 & 0.474 & 0.582 & - \\
CITIC & 0.472 & 0.541 & 0.636 & 0.513 & 0.475 & 0.606 & 0.653 \\
\hline
\end{tabular}

from 2010 to 2012, where D-SIBs are decreasing their systemic importance consistently as analyzed under indicator-based measurement approach. Therefore, influences of D-SIBs upon the rest members of the banking system are reduced. At the same time; non-D-SIBs keep a trend of growing systemic importance, and the systemic importance within banking system is hence more evenly distributed. There are not as large gaps in systemic importance between D-SIBs and nonD-SIBs as systemic importance gap between D-SIBs and nonD-SIBs is no longer as large as it was before, so non-D-SIBs are depicting themselves as more independent entities of the influences of D-SIBs.

\section{Concluding Remarks}

This paper serves as a response to the official BCBS assessment method to determine domestic systemically important banks in China. Our indicator-based measurement approach is much in line with the official BCBS assessment method, while the choice of indicators, as well as method to determine weights within category, is modified to suit real situations in China. While the list of D-SIBs may be obvious, our analysis not only presents current levels of domestic systemic importance, but also displays the trend as time passes.
We find that although still in a high level, the systemic importance of "Big Five" major banks is decreasing during these years. Meanwhile, some joint-stock commercial banks are becoming more systemically important. We suggest that a bucket of Industrial Bank Corporation, China Merchants Bank, and China Minsheng Banking Corporation should be added to the list of D-SIBs under current state, while Shanghai Pudong Development Bank, China Citic Bank, and China Everbright Bank should be included in the watch list for further investigation.

In addition to analysis for individual banks, we also consider the systemic risk issue of the whole banking system. We attempt to investigate how the banks correlate between D-SIBs and non-D-SIBs before and after the recent financial crises using nonlinear approach-Copula in the paper. Our findings of lower correlations between ICBC and non-DSIBs verify that although commonly applied, size only is still not an adequate proxy of systemic risk. "Interconnectedness" and "complexity" play important roles in systemic event in the whole banking system. This market-based approach also provides a cross-check of indicator-based measurement for D-SIBs identification. For banks that are included in the D-SIBs list or watch list, they should be better to check with their overall scores as well as the scores in the five categories every now and then. Special attention should be paid to "interconnectedness" and "complexity", to avoid exposing too much to the banking system. Too frequent interbank activities and too much involvement in derivatives trading that are not for hedging purpose should be carefully examined and avoided if possible.

When viewed as an entire system, D-SIBs display stronger correlations with non-D-SIBs than the individuals, reflecting that the aggregate impacts of D-SIBs have more widespread impacts than the individuals. This gives the regulatory the implications that group sense should be established rather than focusing on the banks individually, in order to avoid "too-many-to-fail" problem. Possible practical proposal of limiting the interbank activities is urgent and essential, to avoid the D-SIBs subsystem becoming too concentrated.

We also find that, during the subprime crisis, D-SIBs actually have contagion effects upon non-D-SIBs, while, during the European debt, no significant contagion effects are 
TABLE 14: Changes of lower tail-dependence coefficients (the European debt crisis).

\begin{tabular}{|c|c|c|c|c|c|c|c|}
\hline & ICBC & $\mathrm{CCB}$ & BOCOM & $\mathrm{ABC}$ & $\mathrm{BOC}$ & Big 5 & Big 8 \\
\hline BBJ & $-4.52 \%$ & $1.20 \%$ & $-14.57 \%$ & $-16.37 \%$ & $-21.89 \%$ & $-6.84 \%$ & $-4.90 \%$ \\
\hline HXB & $-9.34 \%$ & $-7.05 \%$ & $-9.40 \%$ & $-21.19 \%$ & $-19.58 \%$ & $-12.60 \%$ & $-8.33 \%$ \\
\hline CMBC & $-11.14 \%$ & $-4.14 \%$ & $-11.04 \%$ & $-20.74 \%$ & $-12.31 \%$ & $-9.38 \%$ & - \\
\hline $\mathrm{BNJ}$ & $-7.49 \%$ & $-6.27 \%$ & $-22.23 \%$ & $-26.50 \%$ & $-25.13 \%$ & $-14.64 \%$ & $-14.63 \%$ \\
\hline BNB & $-34.52 \%$ & $2.36 \%$ & $-27.34 \%$ & $-23.33 \%$ & $-28.25 \%$ & $-25.19 \%$ & $-19.67 \%$ \\
\hline SDB & $-28.73 \%$ & $-12.60 \%$ & $-18.84 \%$ & $-31.79 \%$ & $-32.10 \%$ & $-23.38 \%$ & $-18.34 \%$ \\
\hline SPDB & $3.57 \%$ & $16.17 \%$ & $-3.00 \%$ & $-8.18 \%$ & $-9.55 \%$ & $1.60 \%$ & $4.07 \%$ \\
\hline IBC & $-14.77 \%$ & $1.28 \%$ & $-9.12 \%$ & $-17.90 \%$ & $-19.11 \%$ & $-12.08 \%$ & - \\
\hline CMB & $-0.03 \%$ & $7.23 \%$ & $-3.21 \%$ & $-7.68 \%$ & $-5.74 \%$ & $-1.61 \%$ & - \\
\hline CITIC & $-15.54 \%$ & $-14.66 \%$ & $-17.87 \%$ & $-27.62 \%$ & $-26.82 \%$ & $-18.22 \%$ & $-16.75 \%$ \\
\hline
\end{tabular}

TABLE 15: Corresponding accounts and adjustment.

\begin{tabular}{|c|c|c|c|}
\hline $\begin{array}{l}\text { Generally adopted } \\
\text { accounts* }\end{array}$ & Chinese accounts ${ }^{* *}$ & Bank of China ${ }^{* * *}$ (BOC) & $\begin{array}{l}\text { Industrial and Commercial Bank } \\
\text { of China }^{* * * *} \text { (ICBC) }\end{array}$ \\
\hline \multirow{2}{*}{$\begin{array}{l}\text { Due from banks and } \\
\text { other financial } \\
\text { institutions }\end{array}$} & $\begin{array}{l}\text { Deposits in banks and other } \\
\text { financial institutions }\end{array}$ & $\begin{array}{l}\text { Due from banks and other } \\
\text { financial institutions }\end{array}$ & \multirow{2}{*}{$\begin{array}{l}\text { Due from banks and other } \\
\text { financial institutions } \\
\text { (i) Nostro accounts } \\
\text { (ii) Placement with banks and } \\
\text { other financial institutions }\end{array}$} \\
\hline & $\begin{array}{l}\text { Lendings to banks and other } \\
\text { financial institutions }\end{array}$ & $\begin{array}{l}\text { Placement with \& loans to banks } \\
\text { and other financial institutions }\end{array}$ & \\
\hline $\begin{array}{l}\text { Reverse repo } \\
\text { agreement }\end{array}$ & Reverse repo agreement & $\begin{array}{l}\text { including: reverse repo } \\
\text { agreement }\end{array}$ & Reverse repo agreement \\
\hline \multirow{2}{*}{$\begin{array}{l}\text { Due to banks and } \\
\text { other financial } \\
\text { institutions }\end{array}$} & $\begin{array}{l}\text { Deposits from banks and other } \\
\text { financial institutions }\end{array}$ & $\begin{array}{l}\text { Due to banks and other financial } \\
\text { institutions }\end{array}$ & $\begin{array}{l}\text { Due to banks and other financial } \\
\text { institutions }\end{array}$ \\
\hline & $\begin{array}{l}\text { Borrowings from banks and } \\
\text { other financial institutions }\end{array}$ & \multirow{2}{*}{$\begin{array}{l}\text { Placement from banks and other } \\
\text { financial institutions } \\
\text { including: repurchase agreement }\end{array}$} & $\begin{array}{l}\text { (i) Deposit } \\
\text { (ii) Money market takings }\end{array}$ \\
\hline \multirow{3}{*}{$\begin{array}{l}\text { Repo agreement } \\
\text { Financial assets at fair } \\
\text { value through profit } \\
\text { or loss }\end{array}$} & Repo agreement & & Repo agreement \\
\hline & \multirow{2}{*}{$\begin{array}{l}\text { Financial assets at fair value } \\
\text { through profit or loss }\end{array}$} & \multirow{2}{*}{$\begin{array}{l}\text { Financial assets at fair value } \\
\text { through profit or loss }\end{array}$} & Financial assets held for trading \\
\hline & & & $\begin{array}{l}\text { Financial assets designated at fair } \\
\text { value through profit or loss }\end{array}$ \\
\hline $\begin{array}{l}\text { Derivative financial } \\
\text { assets }\end{array}$ & Derivative financial assets & Derivative financial assets & Derivative financial assets \\
\hline $\begin{array}{l}\text { Available for sale } \\
\text { financial assets }\end{array}$ & Available for sale financial assets & Available for sale financial assets & Available-for-sale financial assets \\
\hline Personal loans & Personal loans & Personal loans & Personal loans \\
\hline $\begin{array}{l}\text { Corporate loans and } \\
\text { advances }\end{array}$ & Corporate loans and advances & $\begin{array}{l}\text { Loans and advances } \\
\text { (in Corporate loans and } \\
\text { advances }^{* * * *} \text { ) }\end{array}$ & Corporate loans and advances \\
\hline Personal time deposit & Personal time deposit & Personal time deposit & Personal time deposit \\
\hline $\begin{array}{l}\text { Personal demand } \\
\text { deposit }\end{array}$ & Personal demand deposit & Personal demand deposit & Personal demand deposit \\
\hline
\end{tabular}

* Generally Adopted Accounts are exactly the indicators we describe in Section 3.1.1, which are under GAAP.

** Original data from Wind database is organized according to Chinese Accounts.

${ }^{* * *}$ From 2012 annual report of Bank of China (English version).

**** From 2012 annual report of Industrial and Commercial Bank of China (English version).

$*^{* * * *}$ Corporate loans and advances also include discounted bills in financial statement of BOC. 
TABLE 16: Domestic systemic importance of Chinese Banks at 2011.

\begin{tabular}{|c|c|c|c|c|c|c|c|}
\hline Ranking & Bank & Size & Interconnectedness & Nonsubstitutability & Complexity & Public confidence & Final score \\
\hline 1 & $\begin{array}{l}\text { Industrial and } \\
\text { Commercial Bank of } \\
\text { China }\end{array}$ & 0.2078 & 0.1353 & 0.2084 & 0.2300 & 0.2543 & 0.2071 \\
\hline 2 & Bank of China & 0.1588 & 0.1583 & 0.1687 & 0.2648 & 0.1549 & 0.1811 \\
\hline 3 & $\begin{array}{l}\text { Agricultural Bank of } \\
\text { China }\end{array}$ & 0.1568 & 0.0957 & 0.1474 & 0.1227 & 0.2424 & 0.1530 \\
\hline 4 & $\begin{array}{l}\text { China Construction } \\
\text { Bank }\end{array}$ & 0.1649 & 0.0935 & 0.1692 & 0.1167 & 0.1904 & 0.1469 \\
\hline 5 & $\begin{array}{l}\text { Bank of } \\
\text { Communications }\end{array}$ & 0.0619 & 0.0739 & 0.0625 & 0.0643 & 0.0444 & 0.0614 \\
\hline 6 & China Citic Bank & 0.0371 & 0.0707 & 0.0340 & 0.0336 & 0.0149 & 0.0381 \\
\hline 7 & $\begin{array}{l}\text { China Merchants } \\
\text { Bank }\end{array}$ & 0.0375 & 0.0331 & 0.0485 & 0.0355 & 0.0346 & 0.0379 \\
\hline 8 & $\begin{array}{l}\text { Industrial Bank } \\
\text { Corporation }\end{array}$ & 0.0323 & 0.0933 & 0.0265 & 0.0269 & 0.0097 & 0.0377 \\
\hline 9 & $\begin{array}{l}\text { Shanghai Pudong } \\
\text { Development Bank }\end{array}$ & 0.0360 & 0.0710 & 0.0324 & 0.0154 & 0.0139 & 0.0338 \\
\hline 10 & $\begin{array}{l}\text { China Minsheng } \\
\text { Banking Corporation }\end{array}$ & 0.0299 & 0.0421 & 0.0343 & 0.0205 & 0.0124 & 0.0278 \\
\hline 11 & $\begin{array}{l}\text { China Everbright } \\
\text { Bank }\end{array}$ & 0.0233 & 0.0414 & 0.0239 & 0.0285 & 0.0083 & 0.0251 \\
\hline 12 & Huaxia Bank & 0.0167 & 0.0322 & 0.0133 & 0.0054 & 0.0061 & 0.0147 \\
\hline 13 & $\begin{array}{l}\text { Shenzhen } \\
\text { Development Bank }\end{array}$ & 0.0169 & 0.0173 & 0.0162 & 0.0100 & 0.0060 & 0.0133 \\
\hline 14 & Bank of Beijing & 0.0128 & 0.0281 & 0.0094 & 0.0091 & 0.0050 & 0.0129 \\
\hline 15 & Bank of Ningbo & 0.0035 & 0.0054 & 0.0032 & 0.0101 & 0.0015 & 0.0047 \\
\hline 16 & Bank of Nanjing & 0.0038 & 0.0088 & 0.0023 & 0.0066 & 0.0010 & 0.0045 \\
\hline
\end{tabular}

TABLE 17: Domestic systemic importance of Chinese Banks at 2010.

\begin{tabular}{|c|c|c|c|c|c|c|c|}
\hline Ranking & Bank & Size & Interconnectedness & Nonsubstitutability & Complexity & Public confidence & Final score \\
\hline 1 & $\begin{array}{l}\text { Bank of China } \\
\text { Industrial and }\end{array}$ & 0.1639 & 0.1919 & 0.1739 & 0.3093 & 0.1650 & 0.2008 \\
\hline 2 & $\begin{array}{l}\text { Commercial Bank of } \\
\text { China }\end{array}$ & 0.2108 & 0.1383 & 0.2066 & 0.1365 & 0.2532 & 0.1891 \\
\hline 3 & $\begin{array}{l}\text { Agricultural Bank of } \\
\text { China }\end{array}$ & 0.1619 & 0.1033 & 0.1465 & 0.1417 & 0.2420 & 0.1591 \\
\hline 4 & $\begin{array}{l}\text { China Construction } \\
\text { Bank }\end{array}$ & 0.1693 & 0.0910 & 0.1720 & 0.1172 & 0.1922 & 0.1484 \\
\hline 5 & $\begin{array}{l}\text { Bank of } \\
\text { Communications }\end{array}$ & 0.0619 & 0.0836 & 0.0618 & 0.0767 & 0.0423 & 0.0652 \\
\hline 6 & $\begin{array}{l}\text { China Merchants } \\
\text { Bank }\end{array}$ & 0.0376 & 0.0435 & 0.0496 & 0.0433 & 0.0336 & 0.0415 \\
\hline 7 & $\begin{array}{l}\text { Industrial Bank } \\
\text { Corporation }\end{array}$ & 0.0290 & 0.0779 & 0.0269 & 0.0265 & 0.0089 & 0.0338 \\
\hline 8 & $\begin{array}{l}\text { Shanghai Pudong } \\
\text { Development Bank }\end{array}$ & 0.0343 & 0.0665 & 0.0320 & 0.0119 & 0.0132 & 0.0316 \\
\hline 9 & China Citic Bank & 0.0326 & 0.0325 & 0.0335 & 0.0324 & 0.0144 & 0.0291 \\
\hline 10 & $\begin{array}{l}\text { China Everbright } \\
\text { Bank }\end{array}$ & 0.0232 & 0.0373 & 0.0239 & 0.0428 & 0.0079 & 0.0270 \\
\hline 11 & $\begin{array}{l}\text { China Minsheng } \\
\text { Banking Corporation }\end{array}$ & 0.0286 & 0.0389 & 0.0333 & 0.0111 & 0.0110 & 0.0246 \\
\hline 12 & Huaxia Bank & 0.0163 & 0.0367 & 0.0130 & 0.0013 & 0.0054 & 0.0145 \\
\hline 13 & Bank of Beijing & 0.0115 & 0.0187 & 0.0085 & 0.0237 & 0.0048 & 0.0134 \\
\hline 14 & $\begin{array}{l}\text { Shenzhen } \\
\text { Development Bank }\end{array}$ & 0.0114 & 0.0174 & 0.0131 & 0.0039 & 0.0039 & 0.0099 \\
\hline 15 & Bank of Ningbo & 0.0041 & 0.0142 & 0.0032 & 0.0106 & 0.0014 & 0.0067 \\
\hline 16 & Bank of Nanjing & 0.0035 & 0.0083 & 0.0022 & 0.0113 & 0.0009 & 0.0052 \\
\hline
\end{tabular}


TABLE 18: Domestic systemic importance of Chinese Banks at 2009.

\begin{tabular}{|c|c|c|c|c|c|c|c|}
\hline Ranking & Bank & Size & Interconnectedness & Nonsubstitutability & Complexity & Public confidence & Final score \\
\hline 1 & $\begin{array}{l}\text { Bank of China } \\
\text { Industrial and }\end{array}$ & 0.1619 & 0.1648 & 0.1856 & 0.2972 & 0.1725 & 0.1964 \\
\hline 2 & $\begin{array}{l}\text { Commercial Bank of } \\
\text { China }\end{array}$ & 0.2180 & 0.1563 & 0.2008 & 0.1278 & 0.2538 & 0.1913 \\
\hline 3 & $\begin{array}{l}\text { Agricultural Bank of } \\
\text { China }\end{array}$ & 0.1643 & 0.1149 & 0.1408 & 0.2036 & 0.2368 & 0.1721 \\
\hline 4 & $\begin{array}{l}\text { China Construction } \\
\text { Bank }\end{array}$ & 0.1780 & 0.1425 & 0.1761 & 0.1289 & 0.1944 & 0.1640 \\
\hline 5 & $\begin{array}{l}\text { Bank of } \\
\text { Communications }\end{array}$ & 0.0612 & 0.0807 & 0.0610 & 0.0538 & 0.0428 & 0.0599 \\
\hline 6 & $\begin{array}{l}\text { China Merchants } \\
\text { Bank }\end{array}$ & 0.0383 & 0.0501 & 0.0508 & 0.0412 & 0.0347 & 0.0430 \\
\hline 7 & China Citic Bank & 0.0328 & 0.0515 & 0.0325 & 0.0323 & 0.0132 & 0.0325 \\
\hline 8 & $\begin{array}{l}\text { China Everbright } \\
\text { Bank }\end{array}$ & 0.0222 & 0.0467 & 0.0235 & 0.0320 & 0.0072 & 0.0263 \\
\hline 9 & $\begin{array}{l}\text { Industrial Bank } \\
\text { Corporation }\end{array}$ & 0.0246 & 0.0501 & 0.0270 & 0.0208 & 0.0080 & 0.0261 \\
\hline 10 & $\begin{array}{l}\text { Shanghai Pudong } \\
\text { Development Bank }\end{array}$ & 0.0300 & 0.0404 & 0.0312 & 0.0104 & 0.0118 & 0.0248 \\
\hline 11 & $\begin{array}{l}\text { China Minsheng } \\
\text { Banking Corporation }\end{array}$ & 0.0264 & 0.0268 & 0.0307 & 0.0117 & 0.0105 & 0.0212 \\
\hline 12 & Huaxia Bank & 0.0156 & 0.0412 & 0.0130 & 0.0018 & 0.0045 & 0.0152 \\
\hline 13 & Bank of Beijing & 0.0099 & 0.0093 & 0.0079 & 0.0171 & 0.0040 & 0.0096 \\
\hline 14 & $\begin{array}{l}\text { Shenzhen } \\
\text { Development Bank }\end{array}$ & 0.0109 & 0.0146 & 0.0138 & 0.0045 & 0.0038 & 0.0095 \\
\hline 15 & Bank of Nanjing & 0.0028 & 0.0052 & 0.0020 & 0.0094 & 0.0007 & 0.0040 \\
\hline 16 & Bank of Ningbo & 0.0030 & 0.0049 & 0.0032 & 0.0075 & 0.0013 & 0.0039 \\
\hline
\end{tabular}

Table 19: Domestic systemic importance of Chinese Banks at 2008.

\begin{tabular}{|c|c|c|c|c|c|c|c|}
\hline Ranking & Bank & Size & Interconnectedness & Nonsubstitutability & Complexity & Public confidence & Final score \\
\hline 1 & $\begin{array}{l}\text { Bank of China } \\
\text { Industrial and }\end{array}$ & 0.1626 & 0.1965 & 0.1679 & 0.3802 & 0.1762 & 0.2167 \\
\hline 2 & $\begin{array}{l}\text { Commercial Bank of } \\
\text { China }\end{array}$ & 0.2281 & 0.1293 & 0.2194 & 0.1213 & 0.2595 & 0.1915 \\
\hline 3 & $\begin{array}{l}\text { China Construction } \\
\text { Bank }\end{array}$ & 0.1766 & 0.0988 & 0.1706 & 0.1538 & 0.1920 & 0.1584 \\
\hline 4 & $\begin{array}{l}\text { Agricultural Bank of } \\
\text { China }\end{array}$ & 0.1640 & 0.0954 & 0.1414 & 0.1190 & 0.2418 & 0.1523 \\
\hline 5 & $\begin{array}{l}\text { Bank of } \\
\text { Communications }\end{array}$ & 0.0626 & 0.1190 & 0.0625 & 0.0441 & 0.0417 & 0.0660 \\
\hline 6 & $\begin{array}{l}\text { China Merchants } \\
\text { Bank }\end{array}$ & 0.0367 & 0.0474 & 0.0498 & 0.0361 & 0.0340 & 0.0408 \\
\hline 7 & $\begin{array}{l}\text { Shanghai Pudong } \\
\text { Development Bank }\end{array}$ & 0.0306 & 0.0672 & 0.0332 & 0.0122 & 0.0098 & 0.0306 \\
\hline 8 & $\begin{array}{l}\text { Industrial Bank } \\
\text { Corporation }\end{array}$ & 0.0239 & 0.0643 & 0.0279 & 0.0238 & 0.0058 & 0.0291 \\
\hline 9 & China Citic Bank & 0.0278 & 0.0293 & 0.0295 & 0.0306 & 0.0111 & 0.0256 \\
\hline 10 & $\begin{array}{l}\text { China Everbright } \\
\text { Bank }\end{array}$ & 0.0199 & 0.0349 & 0.0241 & 0.0269 & 0.0060 & 0.0223 \\
\hline 11 & $\begin{array}{l}\text { China Minsheng } \\
\text { Banking Corporation }\end{array}$ & 0.0246 & 0.0298 & 0.0308 & 0.0117 & 0.0088 & 0.0212 \\
\hline 12 & Huaxia Bank & 0.0171 & 0.0452 & 0.0150 & 0.0067 & 0.0041 & 0.0176 \\
\hline 13 & Bank of Beijing & 0.0097 & 0.0164 & 0.0079 & 0.0198 & 0.0035 & 0.0115 \\
\hline 14 & $\begin{array}{l}\text { Shenzhen } \\
\text { Development Bank }\end{array}$ & 0.0111 & 0.0197 & 0.0156 & 0.0049 & 0.0038 & 0.0110 \\
\hline 15 & Bank of Nanjing & 0.0022 & 0.0030 & 0.0017 & 0.0069 & 0.0007 & 0.0029 \\
\hline 16 & Bank of Ningbo & 0.0024 & 0.0038 & 0.0029 & 0.0020 & 0.0012 & 0.0025 \\
\hline
\end{tabular}


observed. Major banks are reducing their systemic relevance, while other banks are depicting themselves more independently. It is promising to foresee that Chinese banking system will be more balanced, with reduced dominant power of major banks, and growing tendency of other banks.

\section{Appendix}

See Tables 15, 16, 17, 18, and 19.

\section{Conflict of Interests}

The authors declare that there is no conflict of interests regarding the publication of this paper.

\section{Acknowledgments}

This work has been partially supported by the following Grants: Key Project (no. 71331005), Major International Joint Research Project (no. 71110107026), General Fund (no. 71071151) and Youth Fund (no. 71201143) from the National Natural Science Foundation of China, sponsorship from China Scholarship Council (CSC), and the CAS/SAFEA International Partnership Program for Creative Research Teams.

\section{References}

[1] FSB, IMF, and BIS, "Guidance to assess the systemic importance of financial institutions, markets and instruments: initial considerations," Financial Stability Board, International Monetary Fund, Bank for International Settelment, 2009.

[2] C. Weistroffer, B. Speyer, S. Kaiser et al., "Identifying systemically important financial institutions (SIFIs)," Tech. Rep., Deutsche Bank Research, 2011.

[3] P. Braemer and H. Gischer, "Domestic systemically important banks: an indicator-based measurement approach for the Australian banking system," Tech. Rep., Otto-von-Guericke University Magdeburg, 2012, http://www.vwlgeld.ovgu.de/ vwlgeld_media/downloads/publikationen/FEMM_2012_03.pdf.

[4] BCBS, "Global systemically important banks: assessment methodology and the additional loss absorbency requirement," Basel Committee on Banking Supervision, 2011.

[5] FSB, "Initial group of global systemically important banks (GSIBs)," Tech. Rep., Financial Stability Board, 2011.

[6] FSB, "Update of group of global systemically important banks (G-SIBs)," Tech. Rep., Financial Stability Board, 2012.

[7] FSB, "Update of group of global systemically important banks (G-SIBs)," Tech. Rep., Financial Stability Board, 2013.

[8] J. B. Thomson, "On systemically important financial institutions and progressive systemic mitigation," 2010, http://works .bepress.com/james_thomson/1/.

[9] BCBS, "A framework for dealing with domestic systemically important banks," Final Document, Basel Committee on Banking Supervision, 2012.

[10] T. Adrian and M. K. Brunnermeier, "CoVaR.National Bureau of Economic Research,” Working Paper, 2011, http://www .nber.org/papers/w17454.
[11] C. T. Brownlees and R. F. Engle, "Volatility, correlation and tails for systemic risk measurement," 2012, http://ssrn .com/abstract $=1611229$.

[12] V. Acharya, L. H. Pedersen, T. Philippon, and M. P. Richardson, "Measuring systemic risk," Working Paper 10-02, New York University, 2010.

[13] X. Huang, H. Zhou, and H. Zhu, "Systemic Risk Contributions," Journal of Financial Services Research, vol. 42, no. 1-2, pp. 55-83, 2012.

[14] R. Roengpitya and P. Rungcharoenkitkul, "Measuring systemic risk and financial linkages in the Thai banking system," 2011, http://ssrn.com/abstract $=1773208$.

[15] R. Cont, A. Moussa, and E. Santos, "Network structure and systemic risk in banking systems," 2011, http://ssrn.com/ abstract $=1733528$.

[16] T. Fong, L. Fung, L. Lam, and I.-W. Yu, "Measuring the interdependence of banks in Hong Kong," Working Paper, Hong Kong Monetary Authority, 2009.

[17] E. Bouye, V. Durlleman, A. Nikeghbali, G. Riboulet, and T. Roncalli, "Copulas for finance," 2000, http://mpra.ub.unimuenchen.de/id/eprint/37359.

[18] V. Acharya, M. Richardson, T. F. Cooley et al., "Regulating systemic risk, in," in Restoring Financial Stability: How to Repair a failed System, V. Acharya and M. Richardson, Eds., pp. 283304, John Wiley \& Sons, 2009.

[19] V. V. Acharya, "A theory of systemic risk and design of prudential bank regulation," Journal of Financial Stability, vol. 5, no. 3, pp. 224-255, 2009.

[20] M. Drehmann and N. Tarashev, "Systemic importance: some simple indicators.," BIS Quarterly Review, 2011.

[21] M. Drehmann and N. A. Tarashev, "Measuring the systemic importance of interconnected banks," BIS Working Paper 342, 2011.

[22] C. Zhou, "Are banks too big to fail? Measuring systemic importance of financial institutions," International Journal of Central Banking, vol. 6, no. 4, pp. 205-250, 2010.

[23] M. Boss, H. Elsinger, M. Summer, and S. Thurner, "Network topology of the interbank market," Quantitative Finance, vol. 4, no. 6, pp. 677-684, 2004.

[24] J. Li, C. Liang, X. Zhu, X. Sun, and D. Wu, "Risk contagion in chinese banking industry: a transfer entropy-based analysis," Entropy, vol. 15, no. 12, pp. 5549-5564, 2013.

[25] N. A. Tarashev, C. E. Borio, and K. Tsatsaronis, "Attributing systemic risk to individual institutions," Working Paper, Bank for International Settlements, 2010.

[26] H. Elsinger, A. Lehar, and M. Summer, "Systemically important banks: an analysis for the European banking system," International Economics and Economic Policy, vol. 3, no. 1, pp. 73-89, 2006.

[27] X. Freixas, "Optimal bail out policy, conditionality and constructive ambiguity," Working Paper, London School of Economics Financial Markets Group, 1999, http://repositori .upf.edu/handle/10230/330.

[28] F. Allen and D. Gale, "Financial contagion," Journal of Political Economy, vol. 108, no. 1, pp. 1-33, 2000.

[29] R. Herring, "International financial conglomerates: implications for bank insolvency regimes," in Market Discipline and Banking: Theory and Evidence, G. G. Kaufman, Ed., pp. 99-129, Elsevier, Oxford, UK, 2003.

[30] R. B. Nelsen, An Introduction to Copulas, Springer, New York, NY, USA, 2nd edition, 2006. 
[31] M. Sklar, "Fonctions de répartition à dimensions et leurs marges," vol. 8, pp. 229-231, 1959.

[32] A. . Sklar, "Random variables: joint distribution functions and copulas," Kybernetika, vol. 9, no. 6, pp. 449-460, 1973.

[33] U. Cherubini, E. Luciano, and W. Vecchiato, Copula methods in finance, John Wiley \& Sons, Chichester, 2004.

[34] A. J. Patton, "Copula-based models for financial time series," in Handbook of Financial Time Series, pp. 767-785, 2009.

[35] U. Cherubini and E. Luciano, "Value-at-risk trade-off and capital allocation with copulas," Economic Notes, vol. 30, no. 2, pp. 235-256, 2001.

[36] Y. Malevergne and D. Sornette, "Testing the Gaussian copula hypothesis for financial assets dependences," Quantitative Finance, vol. 3, no. 4, pp. 231-250, 2003.

[37] E. Jondeau and M. Rockinger, "The Copula-GARCH model of conditional dependencies: an international stock market application," Journal of International Money and Finance, vol. 25, no. 5, pp. 827-853, 2006.

[38] J. C. Rodriguez, "Measuring financial contagion: a Copula approach," Journal of Empirical Finance, vol. 14, no. 3, pp. 401423, 2007.

[39] L. Hu, "Dependence patterns across financial markets: a mixed copula approach," Applied Financial Economics, vol. 16, no. 10, pp. 717-729, 2006.

[40] X. Zhu, Y. Li, C. Liang, J. Chen, and D. Wu, "Copula based Change Point Detection for Financial Contagion in Chinese Banking," Procedia Computer Science, vol. 17, pp. 619-626, 2013.

[41] J. Li, J. Feng, X. Sun, and M. Li, "Risk integration mechanisms and approaches in banking industry," International Journal of Information Technology and Decision Making, vol. 11, no. 6, pp. 1183-1213, 2012.

[42] C. Liang, X. Zhu, Y. Li, X. Sun, J. Chena, and J. Li, "Integrating credit and market risk: a factor copula based method," Procedia Computer Science, vol. 17, pp. 656-663, 2013.

[43] J. Li, X. Zhu, C. Lee, D. Wu, J. Feng, and Y. Shi, "On the aggregation of credit, market and operational risks," Review of Quantitative Finance and Accounting, 2013.

[44] D. X. Li, "On default correlation: a copula function approach," Journal of Fixed Income, vol. 9, no. 4, pp. 43-54, 2000.

[45] C. Genest and J. MacKay, "The joy of copulas: bivariate distributions with uniform marginals," The American Statistician, vol. 40, no. 4, pp. 280-283, 1986.

[46] P. Kumar and M. Shoukri, "Evaluating Aortic Stenosis using the Archimedean copula methodology," Journal of Data Science, vol. 6, pp. 173-187, 2008.

[47] CBRC, "2012 annual report of China banking regulatory commission," Tech. Rep., China Banking Regulatory Commission, 2013. 


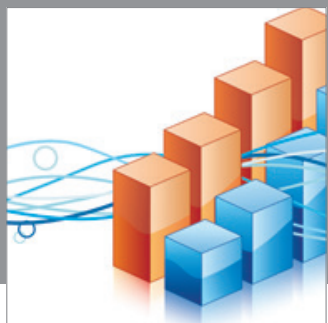

Advances in

Operations Research

mansans

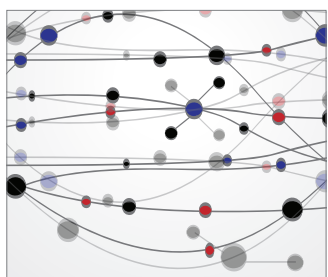

The Scientific World Journal
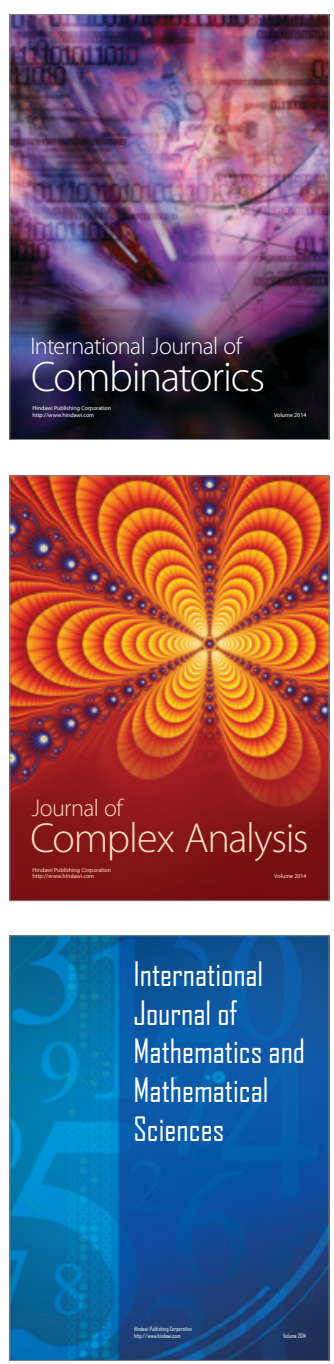
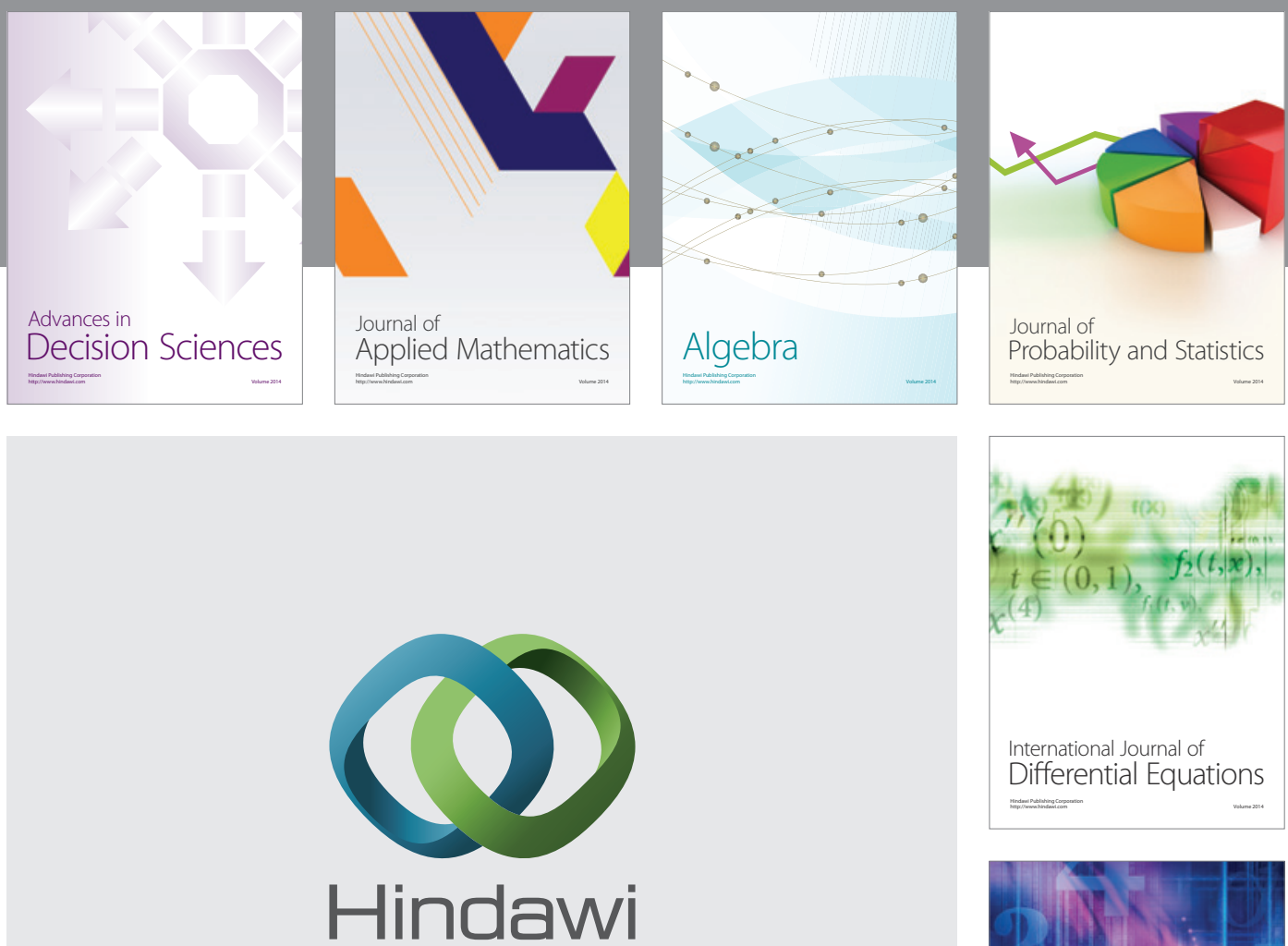

Submit your manuscripts at http://www.hindawi.com
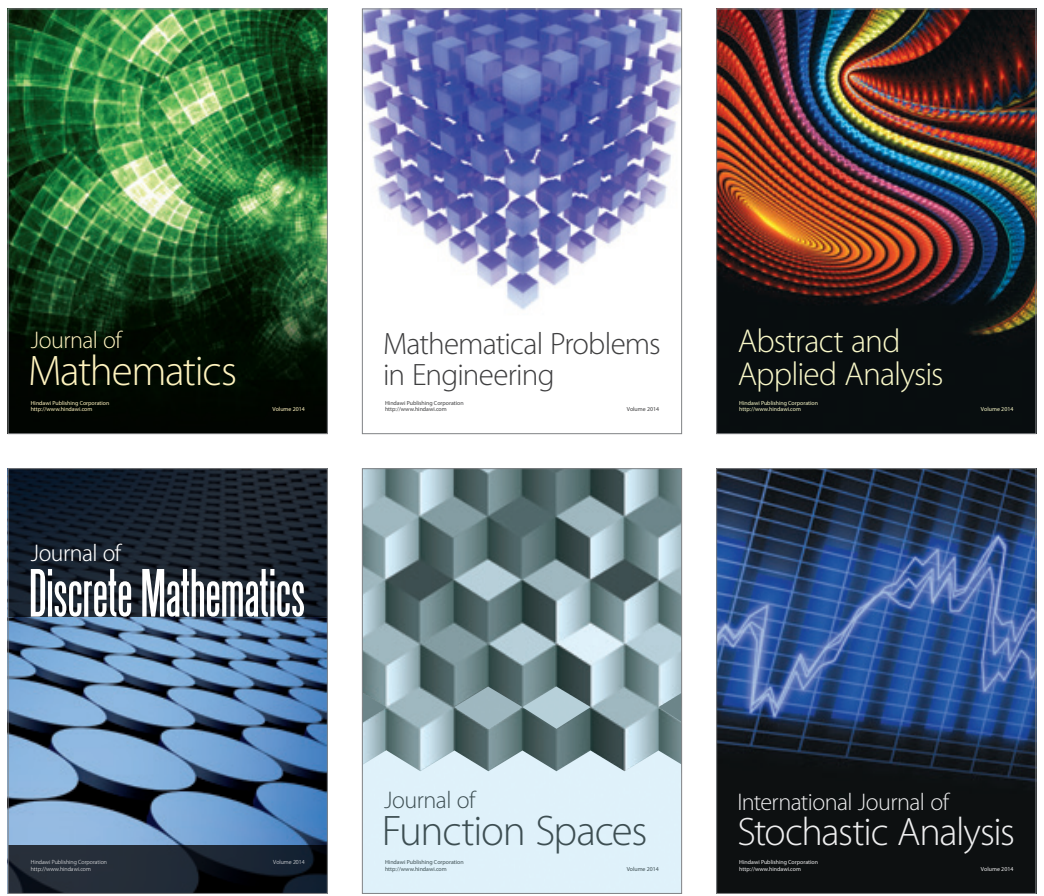

Journal of

Function Spaces

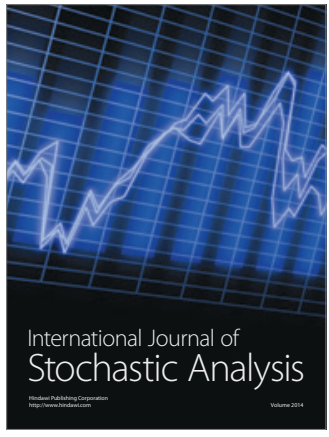

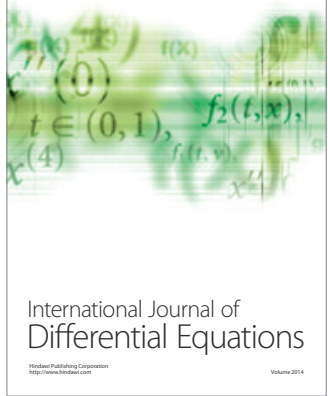
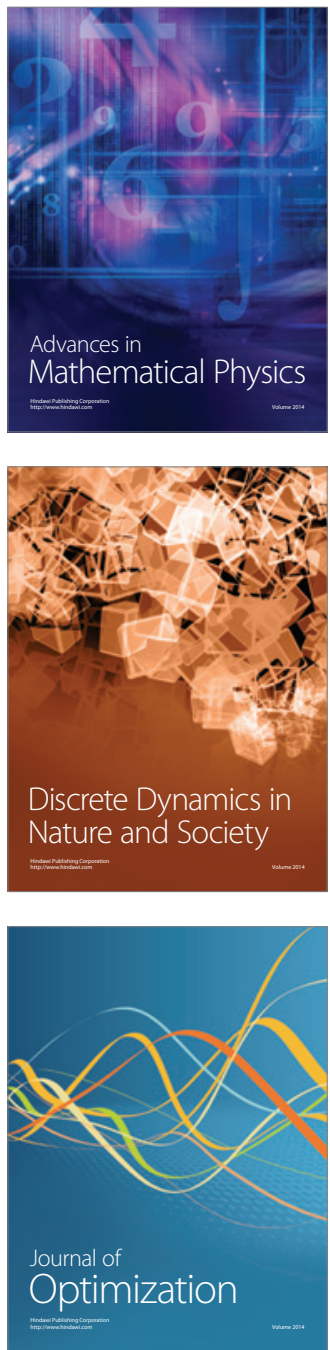